\title{
Caves and speleogenesis at Blomstrandsøya, Kongsfjord, W. Spitsbergen
}

\author{
Stein-Erik Lauritzen ${ }^{1}$
}

\begin{abstract}
:
Lauritzen, S. E. 2005. Caves and speleogenesis at Blomstrandsøya, Kongsfjord, W. Spitsbergen International Journal of Speleology, 35 (1), 37-58. Bologna (Italy). ISSN 0392-6672.

Blomstrandsøya, at Kongsfjord $\left(78^{\circ} 57^{\prime} \mathrm{N}\right)$, Spitsbergen, is within the high arctic, a completely permafrozen zone. The bedrock consists of Paleozoic marbles and has yielded a surprising amount of karst features. Early phases of hydrothermal, possibly Caledonian, speleogenesis and subsequent Devonian karstification with redbed deposits is well documented. 62 active seacaves, and more than 30 relict karst caves were found in the coastal cliffs and in escarpment faces around the island. All caves have very limited extent; they are either quite short, like most of the active sea caves, or they are soon choked by frozen sediments and ground ice after a few meters. The deepest penetration was some $34 \mathrm{~m}$ into the surface cliff. Many of the relict caves are scalloped and display welldefined paragenetic wall and ceiling half-tubes, implying that they are indeed conduits, leading further into the rock mass, beyond their present permafrozen terminations. Most of the speleogenetic volume of the relict caves is ascribed to sub-glacial conditions during stadials, when the site was covered beneath thick ice sheets. In many cases, the present caves were formed by reactivation of pre-existing paleokarst voids. Due to the present intense gelifraction and erosion in the littoral zone, and the relatively constant sea level during the past $9.5 \mathrm{kyr}$, most of the volume of the sea caves can be explained by processes acting during the Holocene.
\end{abstract}

Keywords: karst, speleogenesis, arctic, permafrost, Quaternary, subglacial

Received 27 November 2005; Revised 5 December 2005; Accepted 6 December 2005

\section{SPELEOLOGY IN THE HIGH ARCTIC}

Although there is a prolific literature on speleogenesis in alpine settings, relatively little is published on cave descriptions or speleogenetic studies in high arctic, permafrozen areas e.g. (Ford and Williams, 1989, pp. 489-496; Schroeder, 1979; Juday, 1989; Dixon et al., 1997; Lauriol et al., 2001). Speleogenesis in this climatic zone is enigmatic, as water circulation is restricted to the seasonally active layer, to deep zones beneath the permafrost, or through taliks of various kinds. There is a wide literature on subpermafrost hydrology, describing numerous observations of active water circulation, like open-system pingos, but also many cases of thermal, mineralised water. Water recharge to the sub-permafrost circulation system may take place underneath polythermal glaciers. Since the age of many karst landforms may be much greater than the duration of specific climatic conditions during the Quaternary, it is necessary to consider permafrost dynamics over longer timespans. Relict caves in a permafrozen setting, - like those presented here - or for instance caves in northern Greenland (Davies, 1960; Loubiere, 1987), may either be ascribed to a totally different climatic regime, where permafrost was absent, or to conditions where the caves were part of a talik system i.e. (Lauritzen, 1998). This paper presents new observations on relict

\footnotetext{
${ }^{1}$ Department of Earth Science, University of Bergen

Allegaten 41, N-5007, Bergen, Norway

stein.lauritzen@geo.uib.no
}

and active caves in NW Spitsbergen and discusses their speleogenetic history.

\section{Permafrost and groundwater}

Permafrost is a thermal condition, where ground temperatures beneath a surficial, seasonally thawed zone (the "active layer") is permanently below $0^{\circ} \mathrm{C}$ (Brown, 1970; Price, 1972). Permafrozen areas may be subdivided according to the vertical and lateral extent of frozen zones. In areas of continuous permafrost, frozen ground is regionally continuous and may reach a depth of $500 \mathrm{~m}$ (Brown, 1970). However, it is not present beneath the sea, freshwater lakes or beneath glaciers that are wider than about $400 \mathrm{~m}$ (Werenskiold, 1953). Discontinuous permafrost is limited to depths up to tens of meters and occurs in patches, often restricted to frost-susceptible materials. It occurs at lower latitudes than the continuous variant, and may also exist in the high alpine environment in sub-arctic regions. Taliks are local holes in otherwise continuous permafrost. They may act as sites of groundwater recharge or discharge. Karstification is dependent on flowing, corrosive water, and would therefore be inhibited by permafrost. Exceptions would occur in the active layer and in taliks of various kinds.

In a permafrozen area, two principally different aquifers could exist, the seasonally active suprapermafrost aquifer (within the active layer), and the perennial sub-permafrost aquifer that is confined beneath the permafrozen ground. Sub-permafrost 
groundwater may go very deep, and therefore also transport geothermal heat and brines (Deming et al., 1992). Meteoric recharge of the sub-permafrost system is only possible through taliks. This makes subpolar glaciers in the upland the most likely source of groundwater recharge. Artesian conditions may result when glaciers occupy elevated positions in the surrounding landscape, thus giving rise to pingos and springs that are well documented from arctic areas e.g. (Liestøl, 1976), Fig. 1. Subpolar (polythermal) glaciers are partially cold-based, and frozen only at the lower parts, below the equilibrium line, where it is free from snow. Due to the insulating effect of the glacier ice and snow cover, geothermal heat may cause the upper parts of the glacier to become warm-based, i.e. reach the pressure-melting point of ice. Therefore, this unfrozen zone becomes the most important area of groundwater recharge. Consequently, the extent of warm-based glacier cover would be expected to affect the amount of groundwater recharge and therefore be sensitive to climatic change. Glacial retreat during modern time (for instance, as we have seen on Spitsbergen) may therefore explain numerous historical observations of decreasing flow from many springs (Haldorsen and Lauritzen, 1993). Paradoxically, glacier retreat in this climate increases the snow-free ablation area, where the glaciers become cold-based, in turn shrinking the warm-based upper reaches where aquifer recharge takes place.

\section{Glacier hydrology and karst}

Glaciers may be viewed as aquifers, which convey water through discrete conduits, and to a lesser extent through the intercrystalline vein system. Under "normal" conditions, we may regard a glacier as a perched aquifer, resting on an impervious bed (aquiclude), Fig. 2a. Water transport is intensified along the aquiclude contact through R-channels (Röthlisberger, 1972) and N-channels (Nye, 1965), or through a more irregular, linked cavity system (Walder and Hallet, 1979). R-channels are subglacial conduits where walls and ceiling is formed in ice; they

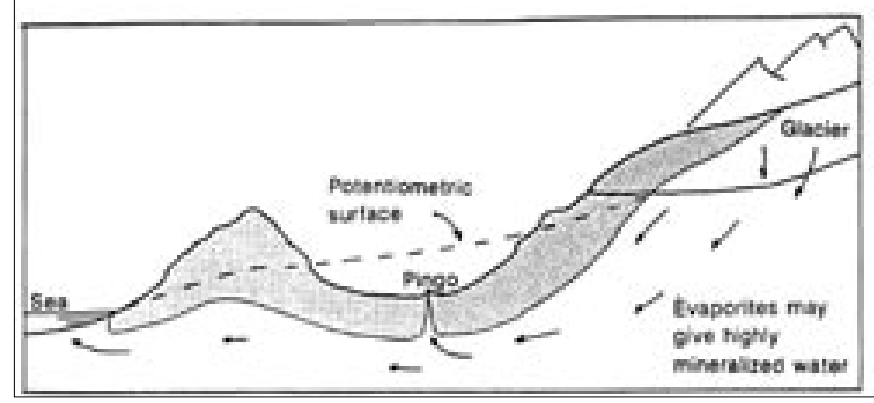

Fig.1. In areas of permafrost (shaded), groundwater recharge may take place from subpolar glaciers in the upland. Groundwater flow is confined beneath permafrost; artesian conditions may force the groundwater up to the surface and form pingo-type springs. After Liestøl (1976). are therefore dynamic features, their size and position in the glacier bed will change with (seasonal) hydraulic conditions. N-channels are subglacial conduits that utilize some depression or fracture in the bedrock so that floor and at least one wall is bedrock; they tend to be more stable towards changes in subglacial hydrology. Basal sliding is largely dictated by water storage and hydrostatic pressures along the aquiclude contact, i.e. the basal water film (Paterson, 1981). Characteristic features of the glacier aquifer are that the water budget is strongly seasonal, and that the interior channel geometry is thought to vary seasonally in concert with the hydrological conditions.

Most interesting and complex cases occur when the glacier aquifer leaks into and interacts with karst aquifers below (Lauritzen, 1991), Fig. 2b. We may expect at least two different effects from this interaction. First, the ice would either erase or even preserve karst forms, depending on their size and permeability prior to glacierization. As mentioned, the sliding velocity of a temperate glacier is directly dependent on the basal water pressure. If the magnitude of leakage from the glacier bed into the karst is large relative to the subglacial water budget, we should expect it to affect the basal sliding velocity of the glacier. Removal of liquid water (i.e. heat) would in turn cause the ice to freeze to its bed. Consequently, plucking and quarrying becomes the prominent erosional effect, as glacial scouring is inhibited. However, if the mechanical strength of the karst forms is greater than the deformation strength of the ice (i.e. larger mogotes or dolines), these landforms may become filled or surrounded with stagnant ice and till. Ice flow is then restricted to zones of deformation higher up in the glacier. The net effect is that smaller karst forms tend to become erased by glacier action, whilst large forms may, in fact, be preserved and infilled with glacial drift.

Second, superposition of glaciers on karst would enhance karstification by increasing hydraulic gradients, particularly in alpine areas. Such an increase in water supply and pressure gradients may stimulate speleogenesis and create caves underneath the snout of alpine glaciers occupying plateaus above deep valleys. Many cases of pro-glacial, invasion-type caves are known (Glazek et al., 1977; Ford and Williams, 1989). In a more generalized situation, the spread of ice sheets during glacial periods made large areas available for subglacial, thawed ground, and karst aquifers could become activated at any altitude within a valley topography, so that phreatic caves could be formed in apparently "impossible" positions. We may call this subglacial speleogenesis. The mechanism was first recognized in Norway by G. Horn $(1935,1947)$, based on much earlier observations on sub-polar glaciers by Werenskiold (1953) and references cited therein; see also the English translation by McCrady Horn, (1978). This mechanism is now generally recognized as a speleogenetic process (Ford, 1984; Ford and Williams, 1989). 


\section{BACKGROUND}

\section{Geographic and geomorphic setting}

Blomstrandsøya, situated opposite the settlement Ny-Ålesund in Kongsfjord ( $\left.78^{\circ} 57^{\prime} \mathrm{N}\right)$, covers an area of some $32 \mathrm{~km}^{2}$, Fig. 3 . The summits reach around 350 $\mathrm{m}$ a.s.l. with steep sides on the NW and $\mathrm{N}$ sides. In this respect, the entire island may be viewed as a huge roche moutonnee, with relatively gentle slopes up-ice (SE) and steep lee-side escarpments ( $\mathrm{N}$ and $\mathrm{NW}$ ). There is also a distinct platform at $10-30 \mathrm{~m}$ a.s.l. around the island. This surface is developed in bedrock and may be viewed as a strandflat, e.g. (Holtedahl, 1996). It is best developed on the SE facing coast, where it is about $1 \mathrm{~km}$ wide. Of the ca. $32 \mathrm{~km}$ circumference, some $2 / 3$ $(20 \mathrm{~km})$ is a rocky shoreline with steep coastal cliffs, the remaining consist of beaches of reworked glacial sediments. Only the central basin and the northern and eastern slopes have any thickness of glacial drift, otherwise the island is barren and rocky.
With the high arctic latitude $\left(79^{\circ} \mathrm{N}\right)$ and a mean annual temperature of -4 to -5 degrees, Svalbard is within the area of continuous permafrost. Based on observations in coal mines (e.g. the Kings Bay mines in Ny-Ålesund), permafrost has a general depth of 200 - 400 m (Liestøl, 1976, 1980).

\section{Bedrock and tectonic setting}

The bedrock consists predominantly of medium to high-grade metamorphic marbles of paleozoic age belonging to the Generalfjella Formation (Hjelle, 1979). This is part of the basement system (Hecla Hoek) with a deformation phase most probably corresponding to the Caledonian deformations in Greenland and Scandinavia. In Blomstrandsøya, the general strike is $\mathrm{N}-\mathrm{S}$ with two syn-metamorphic phases of isoclinal folding, followed by post-metamorphic crenulation and kink-folds associated with west-directed thrusts and imbrications (Thiedig and Manby, 1992). Small patches of unmetamorphosed, post-Caledonian (possibly Devonian) sediments are widely scattered over the area. These redbed deposits represent the eroded remnants of a previously more widespread blanket of Devonian sediments. The sediments are either preserved in wedges associated with faulting and brecciation of the underlying marbles, or they occur in fanshaped bodies filling channels and tubes in the marbles (Thiedig and Manby, 1992). Often, redbed material was also injected into the mesh of calcitic veins that penetrate parts of the marbles. Clastic, in situ redbed infilling in channels and conduits clearly indicate a karstification phase at this time, Fig. 4.

\section{Quaternary geology}

The glacial history of western Spitsbergen is quite well known through the last interglacialglacial cycle. During major glaciations (MIS 6, 5d, 4 and 2), the ice sheets advanced onto to the continental shelf, some $50 \mathrm{~km}$ offshore from the mouth of Kongsfjorden (Mangerud et al., 1998), implying that the Kongsfjord area in those periods was covered beneath several hundered meters of ice. Since the Saalian glaciation (MIS 6), there have been two major interglacials - the Eemian (ca 130 - 118 kyr) and the Holocene (10 kyr present) - and two interstadials - Phantomodden (ca 108 - 75 kyr) and Kapp Ekholm (ca. 50- 25 kyr), (Mangerud and Svendsen,
Fig. 2. Interaction between glaciers and karst, from Lauritzen (1991).

A) 'Normal' situation of a glacier (which may be regarded as an aquifer) situated on an impervious bed. Practically all supraglacial and englacial drainage emerges through the spring at the snout of the glacier. The hydrostatic pressure of the subglacial water, which flows through R-, N- channels, linked cavity systems, or is stored in the subglacial regulation film, plays a major factor (as lubricant) for basa sliding in warm-based glaciers. See text for further discussion.

B) The same glacier situated on a well-developed karst, where subglacial water is pirated into the karst conduits. This may considerably reduce the basal water pressure, thereby impeding basal sliding. See text for further discussion.

Subglacial drainage are reduced 


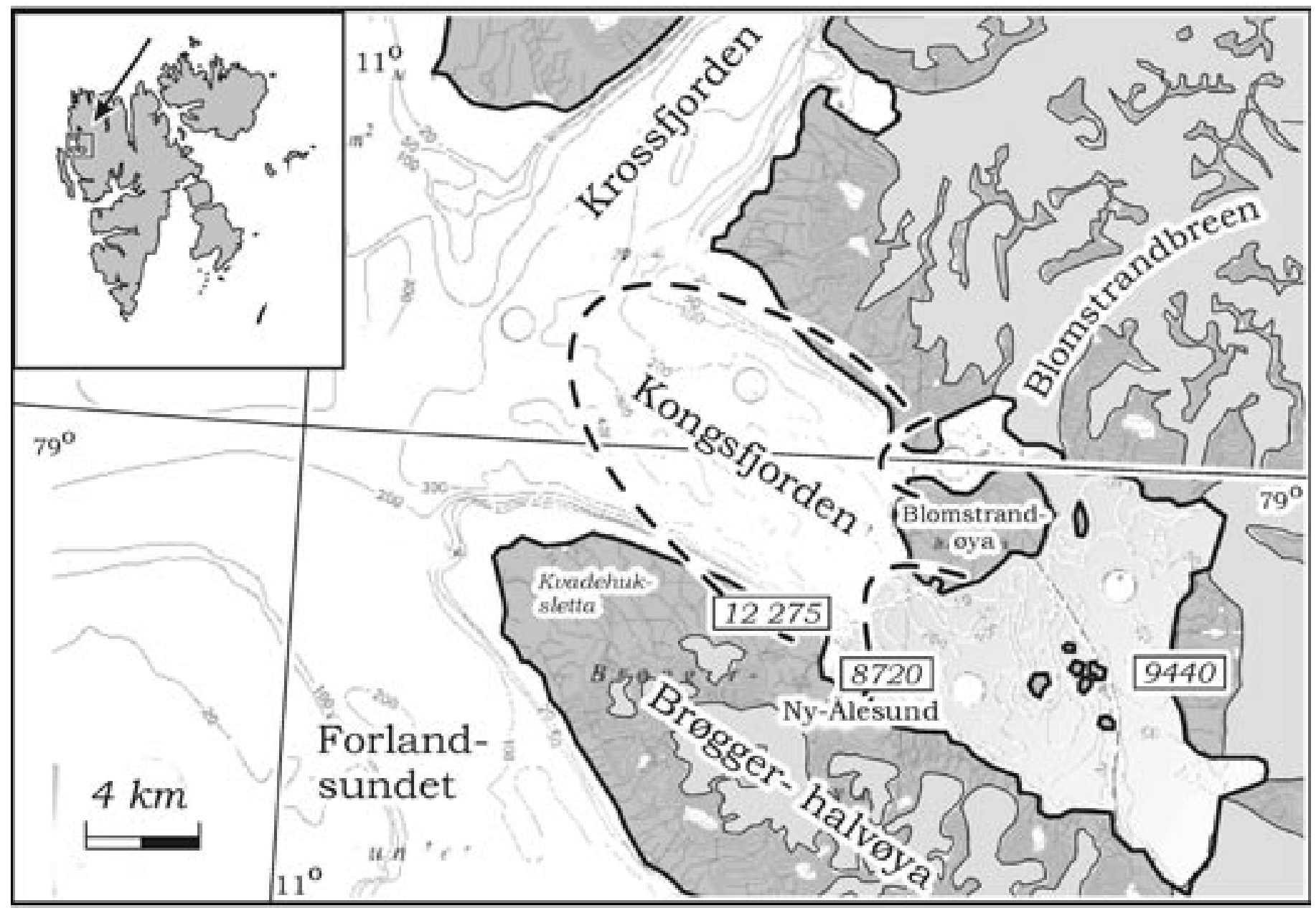

Fig. 3. Location of Kongsfjorden ('Kings Bay') and Blomstrandsøya in NW Spitsbergen. White: ocean with depth contours in grey. Dark shade: open land. Light shade: Glaciers and ice-fields. Dashed lines: extent of the ice sheet during the late Weichselian deglaciation. Numbers in rectangular labels are dates derived from shells in $14 \mathrm{C}$ years $\mathrm{BP}$; these dates are minimum ages for ice-free conditions at the site, implying that the fjord was completely deglaciated at 9400 BP. Deglaciation and age data from Lehman \& Forman (1992). Geography from the Norwegian Polar Institute (NP).

1992). The chronology of the last deglaciation and shoreline displacement in the Kongsfjord area has been reconstructed from shorelines, glacial deposits and ${ }^{14} \mathrm{C}$ dates on associated marine materials (Lehman and Forman, 1992; Mangerud and Svendsen, 1992), Fig. 3. After the Late Weichselian Maximum (19- 18 kyr; Glaciation $\mathrm{G}$ by the workers cited above), deglaciation commenced around $16 \mathrm{kyr}$ and reached the present coastline at $12.5 \mathrm{kyr} \mathrm{BP}$, when a late glacial maximum marine shoreline was formed (MG in fig. 5). At 12.5 ${ }^{14} \mathrm{C}$ kyr BP Kongsfjorden was still filled with ice, but mollusc dates of $9.44{ }^{14} \mathrm{C}$ kyr BP on an interior location in the fjord imply that Blomstrandsøya had emerged from the ice at this point. The corresponding shoreline displacement curve is shown in Fig. 5. At about $9.5 \mathrm{kyr}$ 14C BP, sea level fell rapidly and has stayed constant $( \pm 5 \mathrm{~m})$ since. At the same time, the entire Kongsfjord became icefree (Fig. 3), implying that the coastline of Blomstrandsøya has been exposed to open water at a fairly constant sea level during the last $9 \mathrm{kyr}$.

In historical time, Blomstrandsøya was a peninsula, connected to the mainland by the Blomstrand glacier, which is evident from older maps. Today, the ice front has retreated, leaving a small sound between the island and the ice wall.

\section{Previous work}

Jean Corbel visited Blomstrandsøya in the 1950'ies (Corbel, 1957) pp. 38 - 43 which is perhaps the only previous speleological description of the area: '... normalement les "grottes" de Blomstrand sont soit des failles ouvertes, soit des reinsures de dissolution fossils ... d'origine marine. Elles n'ont pas de profondeur notable...' Corbel recognised the paleokarst with redbed infillings, but he was unable to date them (op. cit. p. 41). Corbel also noted the large sea caves along the coast, visited at least one of them, for which he suggested a paleokarst origin, i.e. a pre-existing karst cave, modified by the thawing and eroding action of seawater. He also noted fresh water ice at its terminal, permafrozen end.

\section{Material and methods}

Existing maps $(1: 100$ 000, contour interval $50 \mathrm{~m})$ issued by Norsk Polarinstitutt (NPI) are of little use for locating karst forms in the field. A new field map of Blomstrandsøya was constructed from existing contour data and details from aerial photographs. In particular, a new coastline was constructed with minute details, allowing the exact location of individual sea caves. In the absence of GPS (1992), 


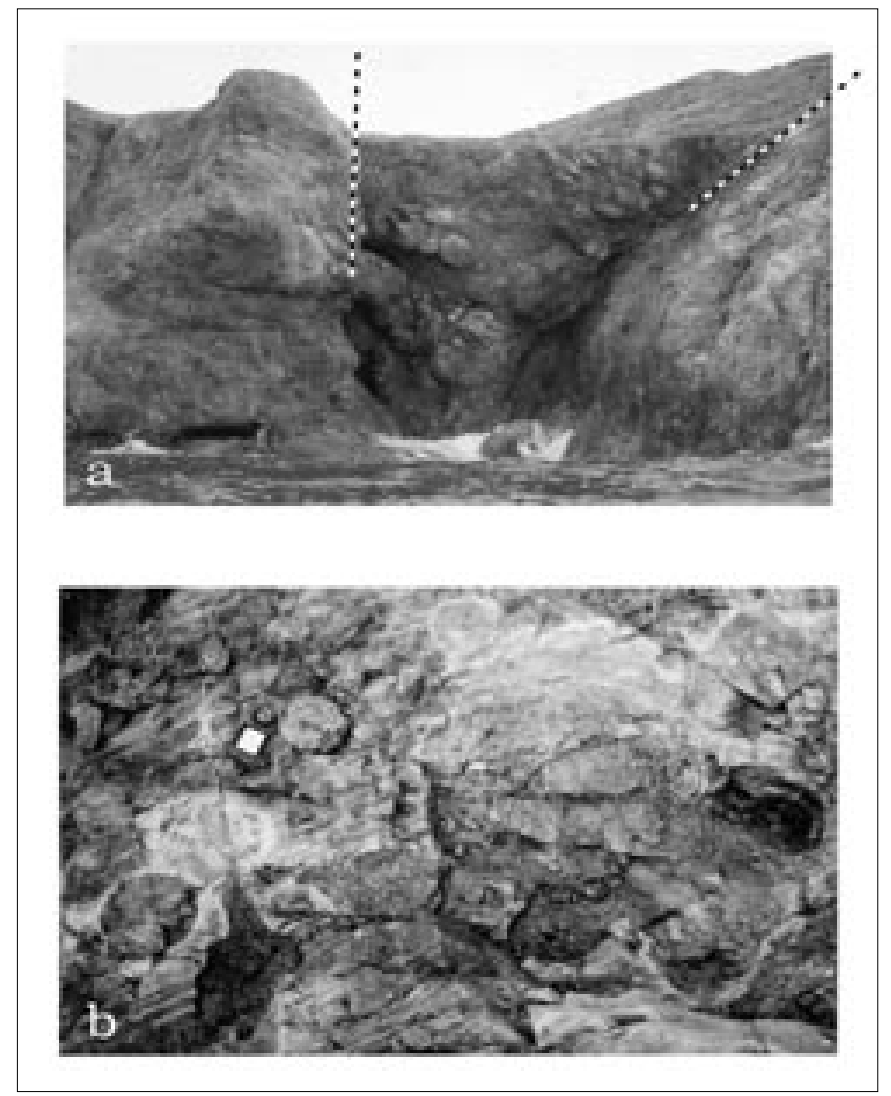

Fig. 4. Various types of redbed (Devonian?) inliers. a) Tectonic wedge of boulder breccio-conglomerate, northern shore of Blomstrandsøya. b) Vertical paleokarst conduits filled with redbed sediments, west of Ny-London. (Photo a: S.E Lauritzen; b : Narve Ringset).

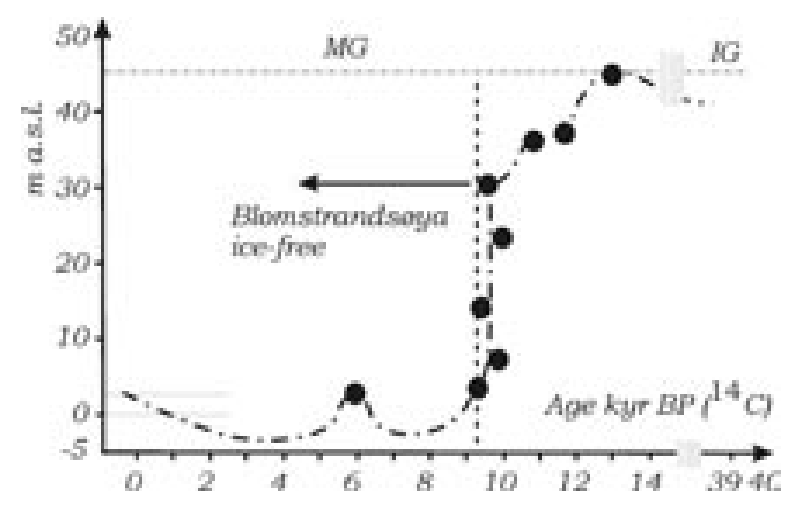

Fig. 5. Shoreline displacement curve for the mouth of Kongsfjorden, after Lehman \& Forman (1992). At about $9.5 \mathrm{kyr} 14 \mathrm{C} \mathrm{BP}$, sea level fell rapidly and has stayed constant $( \pm 5 \mathrm{~m})$ since. At the same time, the entire Kongsfjord became icefree (Fig. 3), implying that the coastline of Blomstrandsøya has been exposed to open water at a fairly constant sea level during the last 9 kyr. MG: late Weichselian marine limit, IG: interstadial/interglacial.

objects were located by using an aneroid altimeter and compass bearings to prominent landmarks. Seacaves were located by boat off-shore; some could be explored by boat or by wading using survival suits. Secondary calcite was dated by the U-series method, using conventional laboratory techniques

\section{RESULTS AND DISCUSSION}

The observed karst landforms (caves) may be divided into three main categories, according to morphology and infilling material: pre-glacial or paleokarst caves, subglacial caves and active, post-glacial (marine abrasion) caves. The classification only refers to the most obvious genetic mode and does not exclude the possibility of a polygenetic origin, which is certainly the case for several of them. Closed depressions and bogaz forms are also described and discussed here, because caves are in some cases associated with them. Topography, geology and karst landforms are shown in Fig. 6; a key to specific objects discussed in detail is shown in Fig. 7.

\section{Closed depressions and bogaz forms.}

Dolines of moderate size (up to about 10 m diameter) are only found close to the sea-shore, where coastal caves provide local taliks. Here, collapse and suffusion dolines have developed in conjunction with vertical fissures and blow-holes (Fig. 11a,d \& e). Similar, thermal talik (suffusion) dolines are also known from shingle beds on elevated beach deposits elsewhere in Spitsbergen (Salvigsen and Elgersmaa, 1985).

Much larger and possibly older karst depressions also exist, of which lake Irgenstjernet is the best example (Lauritzen, 1998). The small lake is hosted inside a closed depression, some $500 \mathrm{~m}$ in diameter, Fig. $6 \&$ 8. Most of the circumference is bedrock, although the southern edge was covered in snow and probably has a till blanket. The depression is situated on the summit of a major hill in the flanks of Irgensfjellet, a peculiar topographic situation that is not easily compatible with a glacial origin. In simple terms, one would expect glacial overdeepening to operate in topographic lows, where an ice stream is accelerated; not on the summit of a topographic high, which would tend to divert flow rather than concentrate it. The fact that it is not filled up with drift from overriding ice sheets, is compatible with the raised topographic position, presumably above sediment-laden basal ice. Moreover, according to the anticipated mechanism of interaction between large karstforms and glaciers discussed above, we should expect the depression to become filled with (relatively clean) stagnant ice so that ice flow would pass over it, not into it. In spite of the fact that glaciers indeed create lakes, the local circumstances at Irgenstjernet strongly suggest that the depression is of karstic origin; the large size and the fact that it supports a lake today points to its relict nature and great age. The present lake drains underground through a shallow, supra-permafrost system to a small spring some hundred meters to the north. The infiltration is therefore inhibited by permafrost because the lake itself is not wide or deep enough to support a talik, also it is far too large to have been formed by post-glacial corrosion. Hence, the depression is relict and of pre- or interglacial origin.

Bogaz-forms (i.e. 'karst streets' or 'corridors') occur in three places on the island. The largest and most 


\section{Blomstrandsøya, karst landforms (O2005 S.E. Lauriten}

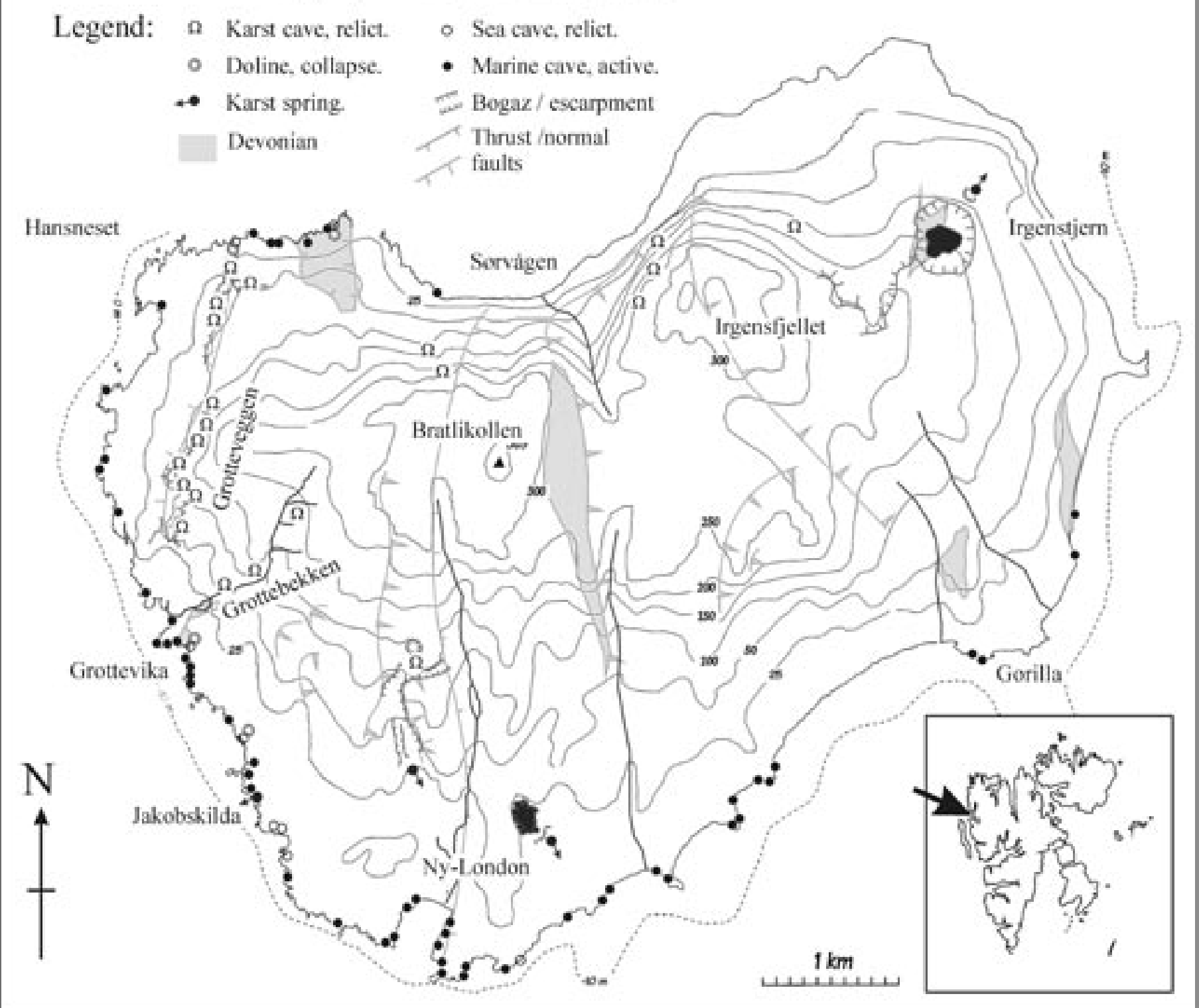

Fig. 6. Geology and speleology of Blomstrandsøya. Geological features adapted from Thiedig \& Manby (1992). Nameplaces are in part official (Norsk Polarinstitutt) and unofficial.

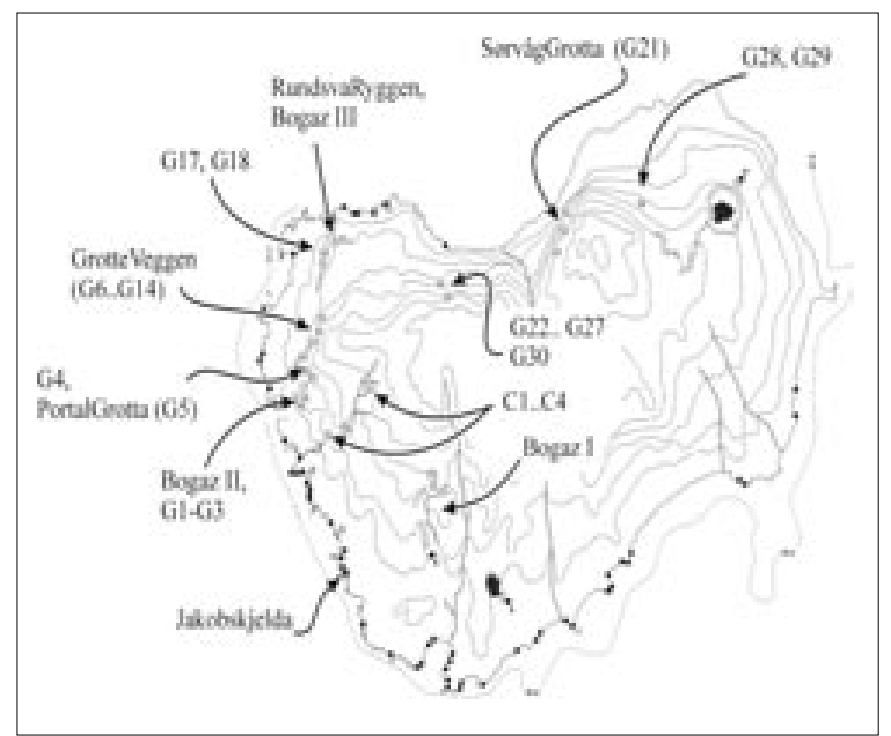

Fig. 7. Locations of objects that are discussed in detail in the text complex feature ('Bogaz I) is situated north of $\mathrm{Ny}$ London. This is a complex melange of collapsed and frost-shattered amphitheatre- shaped depressions and karst streets. Small caves are found in hanging positions in these escarpments. The locality appears to be guided by a series of imbricated faults with intensive fracturing (Thiedig $\&$ Manby op cit).

Bogaz II, situated in the slopes between Grotteveggen and Grottevika, comprises a $150 \mathrm{~m}$ long, linear karst street that cuts across a ridge in the landscape, Fig. 9. It is oriented N-S, i.e parallel with the shoreline and cliffs. This orientation is also compatible with the major ice flow through Kongsfjorden. The bogaz is about $20 \mathrm{~m}$ wide, with relatively steep walls, the floor is covered with cryoclastic regolith. Solifluction lobes in its southern end indicate that there is finegrained glacigenic material beneath the regolith. The apex comprises a pronounced knick-point where the bedrock floor is also exposed. Several small caves and 


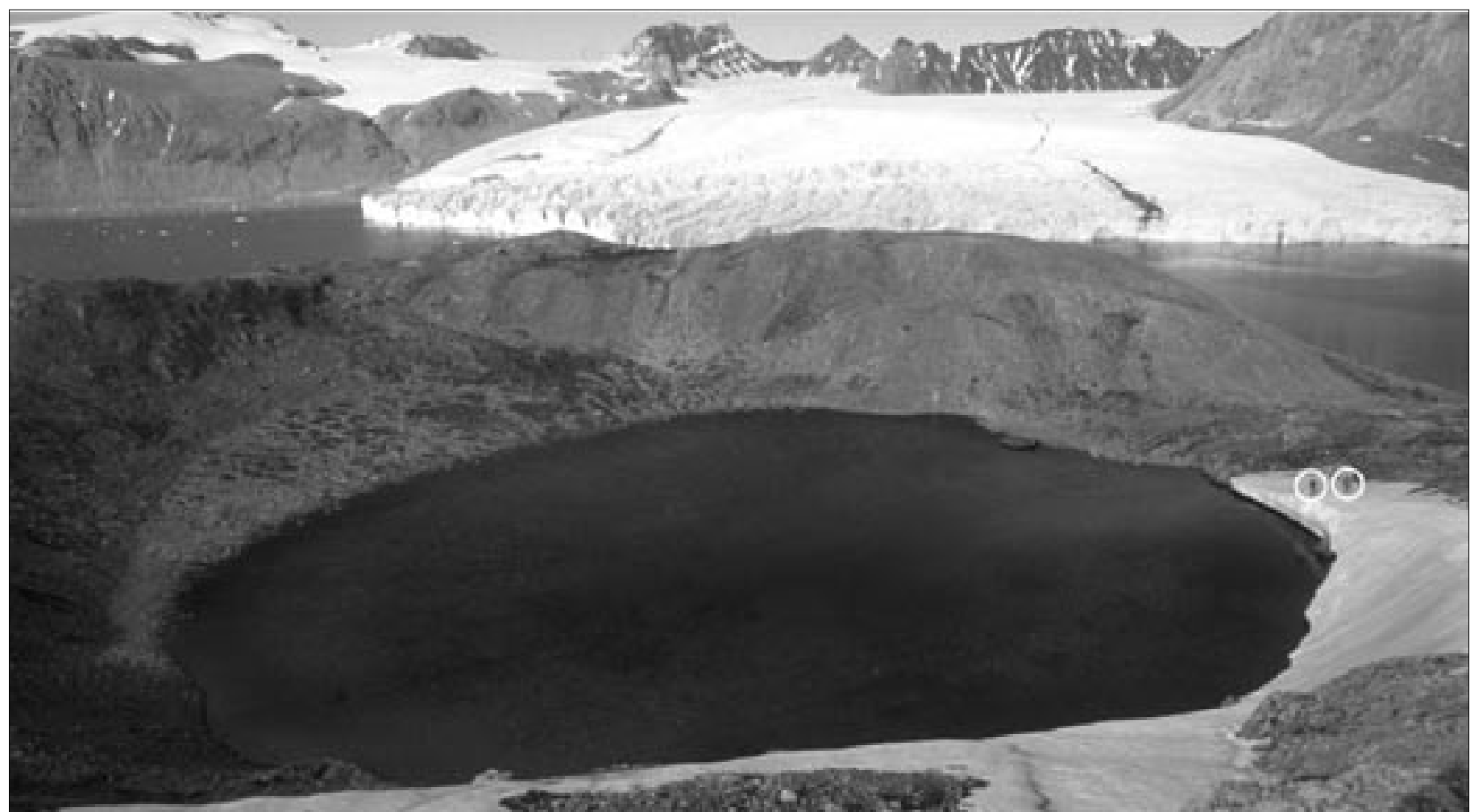

Fig. 8. Irgenstjernet, a large closed depression on the eastern summit of the island. Persons for scale in circles on the snowpatch, Blomstrandbreen in the background, looking east.

rock-bridges are exposed here. These caves display smooth walls and tube-shaped cross sections where they are not damaged by frost shattering. They either become too tight or choked with frozen material.

Bogaz III is situated in Rundsvaryggen, east of Hansneset, Fig. $6 \& 7$. It is much less pronounced than the other two, in part transformed into a small canyon carrying a meltwater stream. It is oriented $\mathrm{E}-\mathrm{W}$, in the direction of the ice movement on the northern part of the island. One major, relict cave 'Dobbeltgrotta' G-18, has a similar orientation and is situated nearby (vide infra).

In summary, all three landforms are oriented parallel with known or anticipated ice movement directions around the island, as judged from glacial striae and general topography. This is compatible with the widely-held view that bogaz-like forms or 'shallow corridor karst' may have accommodated and been formed by subglacial drainage routes (Ford, 1984; Ford and Williams, 1989).

\section{Active caves and sea caves}

Due to the permafrost, 'active' caves, i.e. caves that are in contact with (aggressive), liquid water, are only found within the shallow active layer and together with marine taliks. Hence, such caves are almost exclusively sea caves situated in the steep coastal cliffs around the island.

The only significant supra-permafrost cave found, is the small resurgence cave named Jakobskelda (Fig. $11 \mathrm{~b})$. This is a small tubular passage, situated some $5 \mathrm{~m}$ above sea level, discharging a small brooklet of meltwater of relatively low electrical conductivity. The

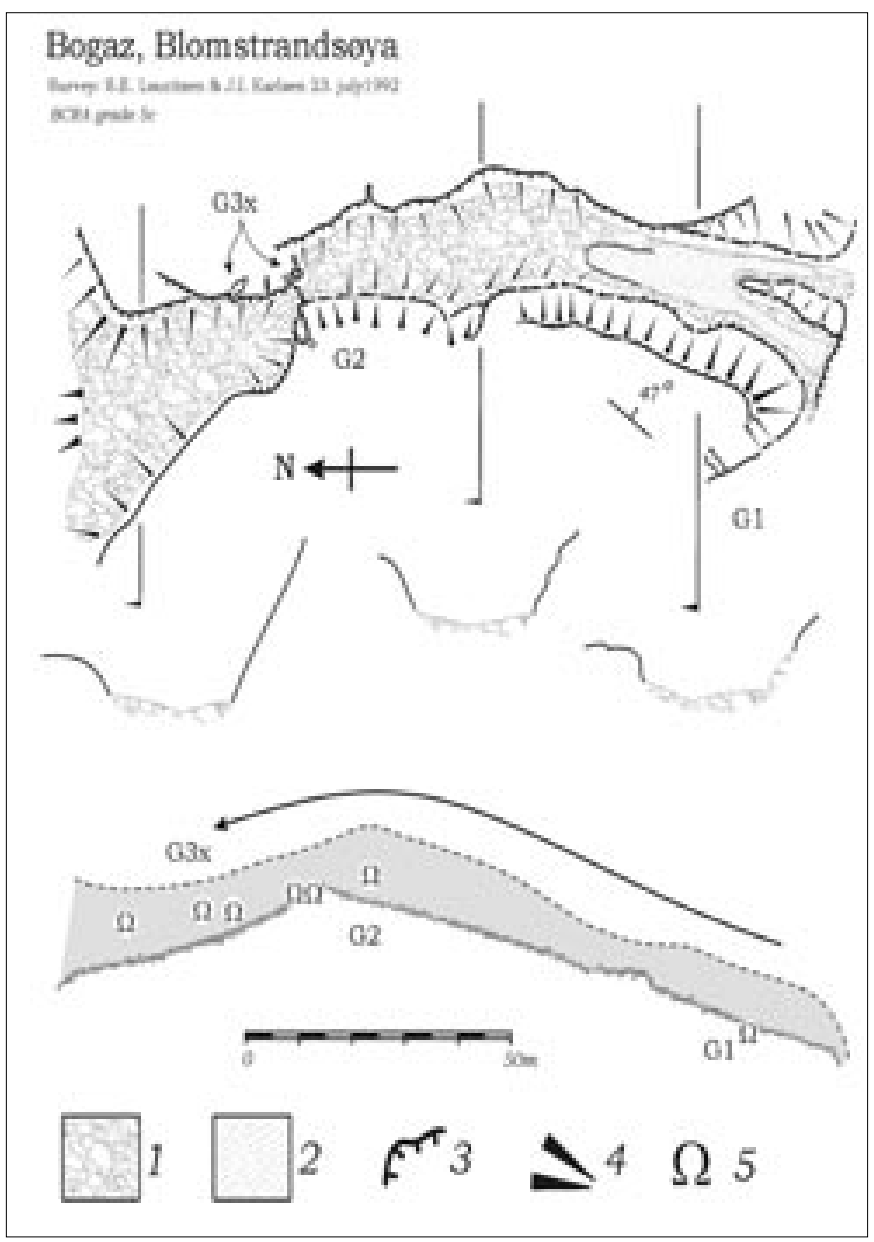

Fig. 9. Bogaz with small caves on the western side of Blomstrandsøya. Plan map (top) and longitudinal section (bottom), arrow indicates inferred ice and water flow. Legend: 1: cryoclastic regolith. 2: soliflucted mix of soil, glacial drift and cryoclastics. 3: steep edge. 4: slope. 5: cave. 
cave is only a few meters deep and ends in cryoclastic debris, under which the little stream emerges. Only the outer (nonfrozen?) part of the cave display a small vadose trench.

62 active sea caves were located around the rocky coastline, Fig. $10 \& 11$. Their size varies from relatively tight fissures to large, arched features ( $10 \mathrm{~m}$ wide), which could be explored by boat. Regular, arched entrances are found in relatively homogeneous rock, suggesting that such profiles are a result of spalling and dissipation of stress, similar to a glacier mouth (Fig. 10e). Where prominent tectonic structures occur, like thrustplanes and normal faults, the cross sections become irregular and dictated by these structures (Fig. $10 \mathrm{c}, \mathrm{f}, 11 \mathrm{e})$, although low dip faultplanes can be seen to guide arched entrances as well (Fig. 10d, 11c). The caves are never very long; the maximum horizontal distance explored from the surface was about $15 \mathrm{~m}$. The caves either terminate in vertical rock walls (deep water, Fig 10a, b), or in small shingle beaches (Fig. 10d, g, 11a, c). Deeper terminations (fissures) taper out to impenetrable dimensions and are always frozen (Fig. 10h). The seacaves generally lack sediment chokes and ground ice plugs as is found in the relict caves in the high cliffs.

\section{Relict caves}

More than 30 caves or cave entrances have been detected in cliffs around the island, Fig. 6, 7, $12 \&$ 13 and Table I. None of these caves have previously been reported. Compared with previous reports (e.g. Corbel op. cit.), they are new and quite unexpected discoveries. Although none of these caves could be explored to any great depth due to ground ice, they may indeed be quite deep and they are certainly karst conduits, distinctly different from the marine abrasion caves described above.

Caves $\mathrm{C} 1-\mathrm{C} 4$ are truncated counduits exposed in the walls and slopes of Grottebekken streamcourse. In spite of being quite small, they are fracture-guided tubes (Fig. 12a). G1- G3 are associated with Bogaz II, as discussed above. G4 and G5 are situated in the cliff face named 'Grotteveggen' (cave wall). G4 (Fig. 14) is the smallest of them. It is filled with red soil and cryoclastic debris and ends after eight meters in permafrost. The slight break in slope of the cave floor as seen in the longitudinal section may be viewed as the front of a small solifluction lobe. Scalloping on the eastern wall indicates former water flow out of the cave. Portalgrotta (G5), at $72 \mathrm{~m}$ a.s.1., is the largest and most spectacular of the caves, having a large portal entrance that is visible from a great distance (Fig. $12 \&$ 15). Most of the entrance has smooth, scalloped walls, indicating influent (northwards) water movement (Fig. 12f). Scallops further into the cave confirm this observation. The floor is covered with the same mixture of red soil, cryoclastic blocks and gravel. The cave terminates in a permafrozen choke $34 \mathrm{~m}$ from the surface cliff. The extensive, $\mathrm{N}$ $\mathrm{S}$ trending cliff wall, Grotteveggen displays about 10 entrances that require technical climbing to reach. Underneath many of these entrances, the cliff face is stained red from a 'bleed' of sediments out of the caves, indicating that they (like the accessible G4) have redbed-derived fills. G17 and G18 (Fig 13a) are located underneath the escarpment through which Bogaz III is cut, i.e. they would be on the lee side of ice movements coming out Sørvågen sound. G17 is a straight, $9 \mathrm{~m}$ deep passage, ending in frozen regolith. G18 is a complex, partially unroofed feature. The area named Rundsvaryggen ('roche moutonnée hill') displays several glacially striated whaleback forms, several of which have cave entrances underneath their lee-side escarpment (G15 \& G16, Fig. 13b), and a few also have a corresponding 'entry' at their up-ice slopes. These holes also bleed redbed fines.

A series of very interesting cave fragments are found in the steep cliffs around Sørvågen. The 'Hole-in-thewall', or Sørvåggrotta (G21) is a spectacular opening, Fig. 13g, 16. The cave possesses several short side passages and a small aven and it is distinguished by having small speleothems. These speleothems appear as basically hardened moonmilk, forming rounded drapes and stalactitic forms. Some frostshattered specimens were collected for dating. As seen in many other places in Svalbard, speleothems are almost absent, but do occur in caves underneath bird colonies. This is also the case here, suggesting that biogenic $\mathrm{CO} 2$ and organic acids from the guano may trigger precipitation of secondary carbonate. The inner surfaces of G21 are quite frost-shattered, although scallops of indeterminate direction are found on the inner wall.

Perhaps the most significant caves occur in the Brattlikollen face. Here, a series of phreatic caves are situated at high altitude $(226-280 \mathrm{~m}$ a.s.1.). G22, Takrøret ('the rooftube') is a cave with a wellpreserved phreatic morphology, Fig 17.

There are several ceiling and wall half-tubes; these are well scalloped and are continous with phreatic side passages that branch out from the main chamber, Fig 13d..f. The phreatic passages are developed asymmetrically around the guiding fracture, so that the tube is widened much more above the guiding fracture than below it. Collectively, these features are characteristics of paragenetic development; the passages evolved under phreatic or epiphreatic conditions in contact with a sediment fill (Lauritzen and Lundberg, 2000). Possible remains of this sediment fill can be seen as patches of a brown, clayey diamicton still in contact with the floor and walls of the tubes. There are a number of other small scalloped caves (tubes) in the area around G22, of which G27 contains fragmented deposits of carbonate-cemented quartz gravel. The cement was dated with $\mathrm{U}$-series technique (vide infra).

The main passage of G29, 'Termalgrotta', situated in the eastern flanks of Irgensfjellet, intersects a 

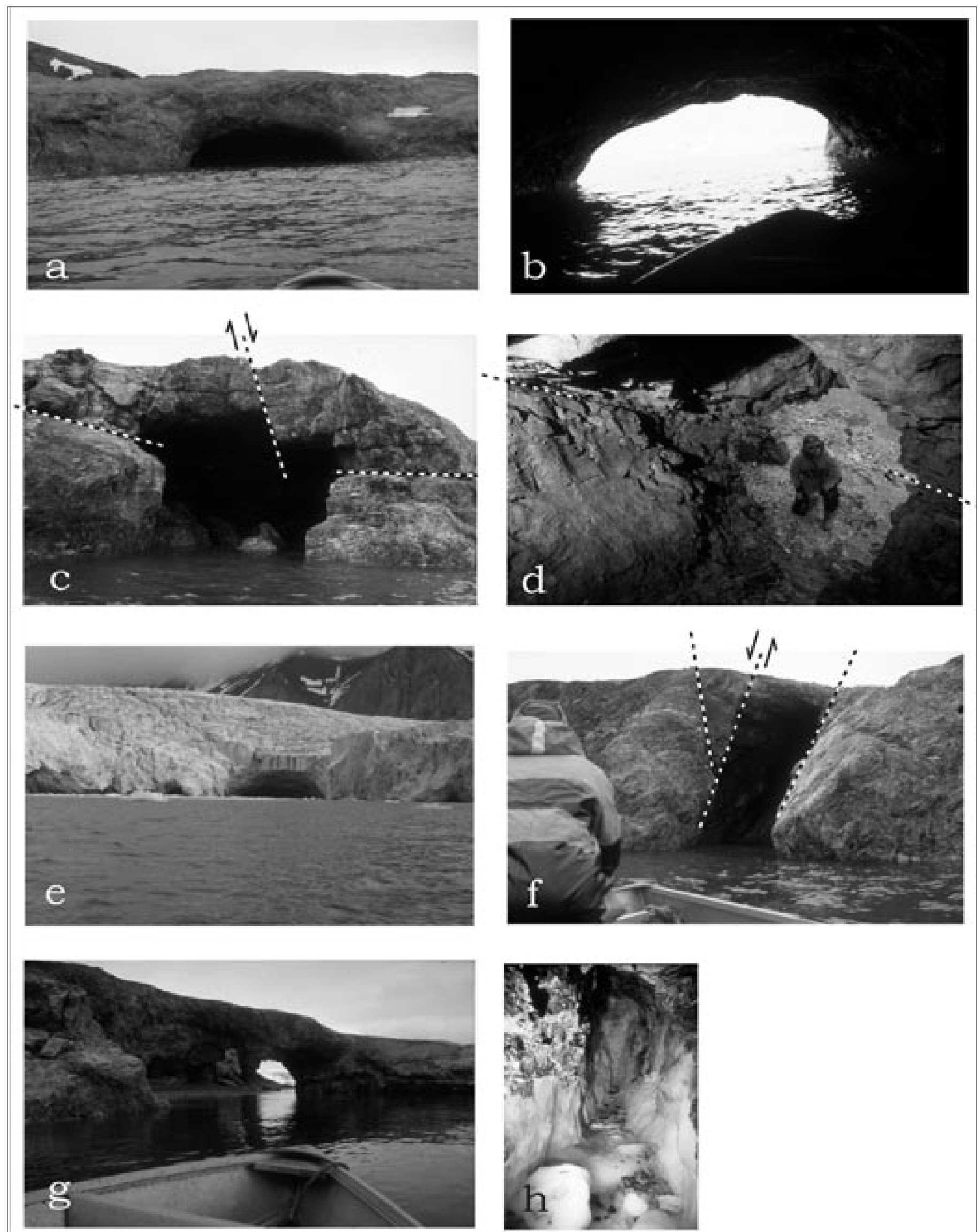

Fig. 10. Various sea caves along the rocky shores of Blomstrandøya. a) Arched entrance to a chamber with fairly round cross section, southern shore. b) Interior of same. c) Large seacave with irregular outline, guided by faults and thrustplane, northern shore. d) Interior of seacave with beach, Grottevika landing site. Guiding fracture is a sheared bedding plane. e) Mouth of Blomstrandsbreen, illustrating an arched 'sea-cave' entrance, the shape being dictated by spalling in a relatively homogenous material, cfr. a) and b). f) Fissure-guided sea-cave, guided by faults. The cave has exploited the damage zone between the two faults. g) Small alcoves and a through cave, Ny-London Bay. h) interior of a deep seacave, frozen seawater and ground ice. All photographs: S.E. Lauritzen. 

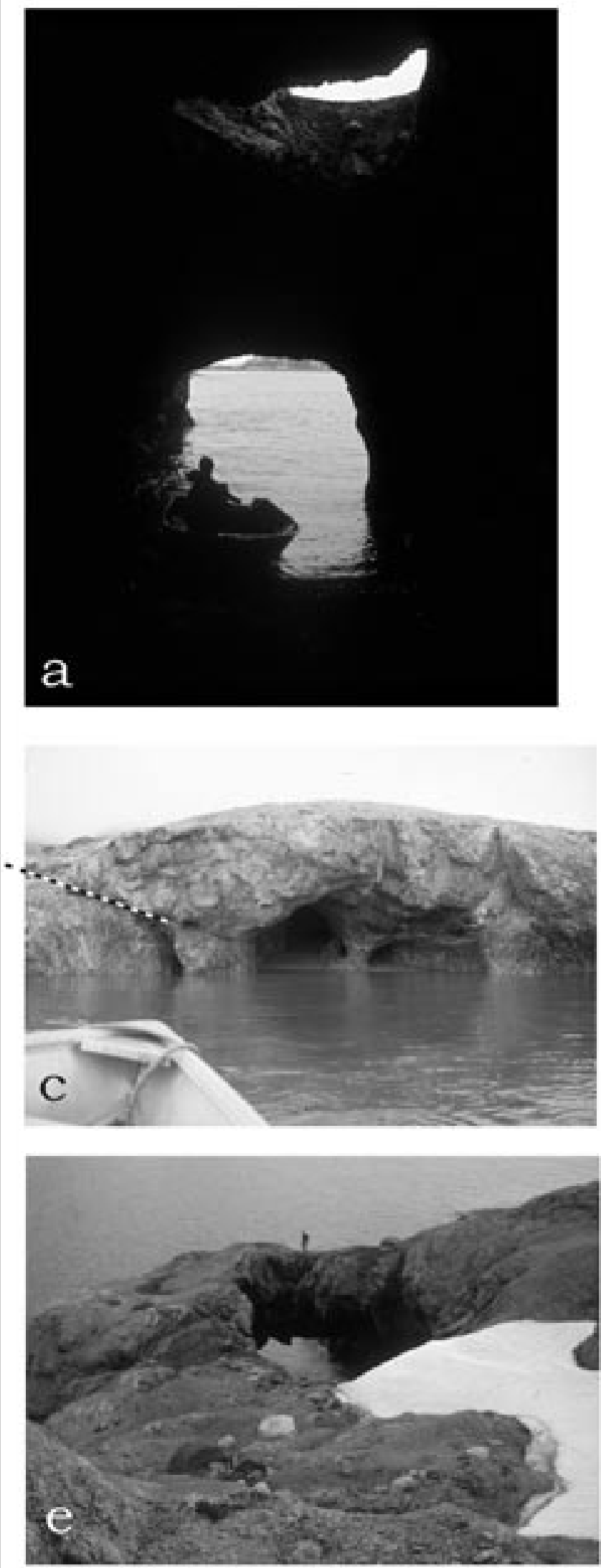
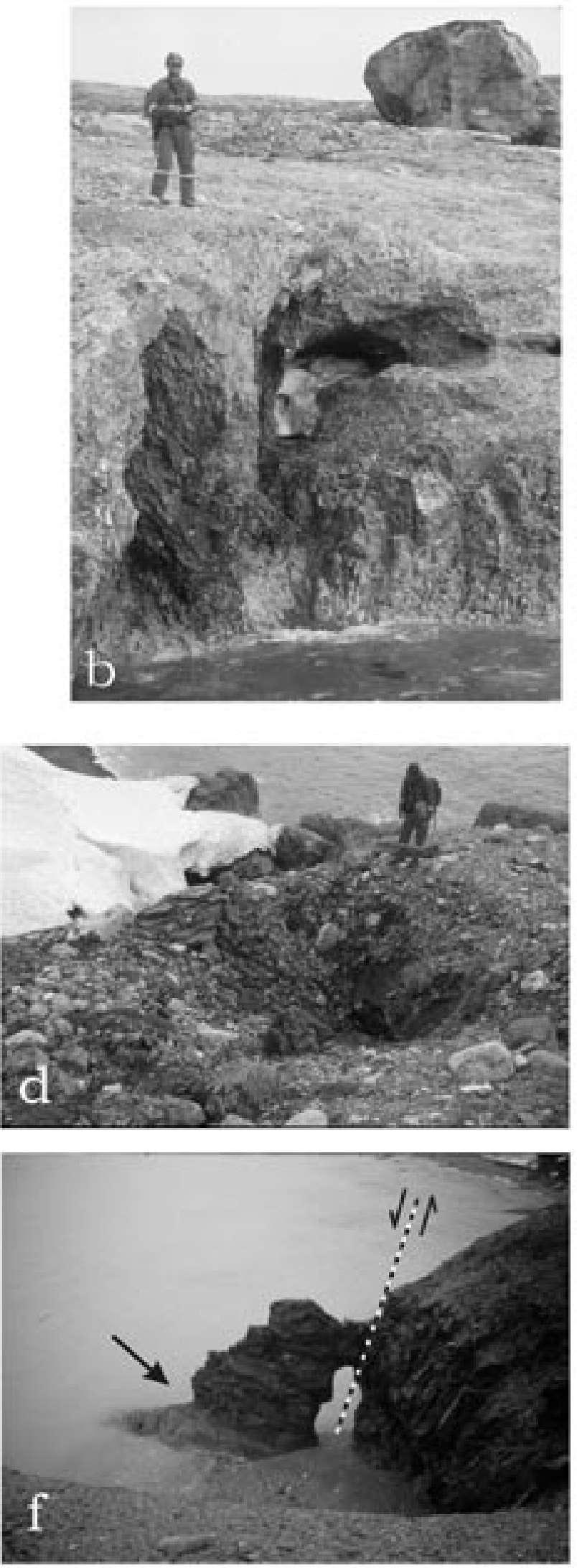

Fig. 11. Various sea caves along the rocky shores of Blomstrandøya. a) Large seacave guided by vertical fractures, with well-developed blowhole. Southern shore, this cave was also depicted by Corbel (1957). b) Jakobskilda, a small karst spring emerging in the coastal cliff face. The spring conveys supra-permafrost water. c) Small seacaves, Ny-London bay, guided by thrustplane. d) Suffosion doline developed in glacial drift through a blowhole. Southern shore. e) Large arched seacave, with cenote-like blowhole, developed in contact with a Devonian inlier, northern shore. f) Arched sea-stack and remnants of cave, northern shore. Note the abrasion notch at normal tide level. All photographs: S.E. Lauritzen. 

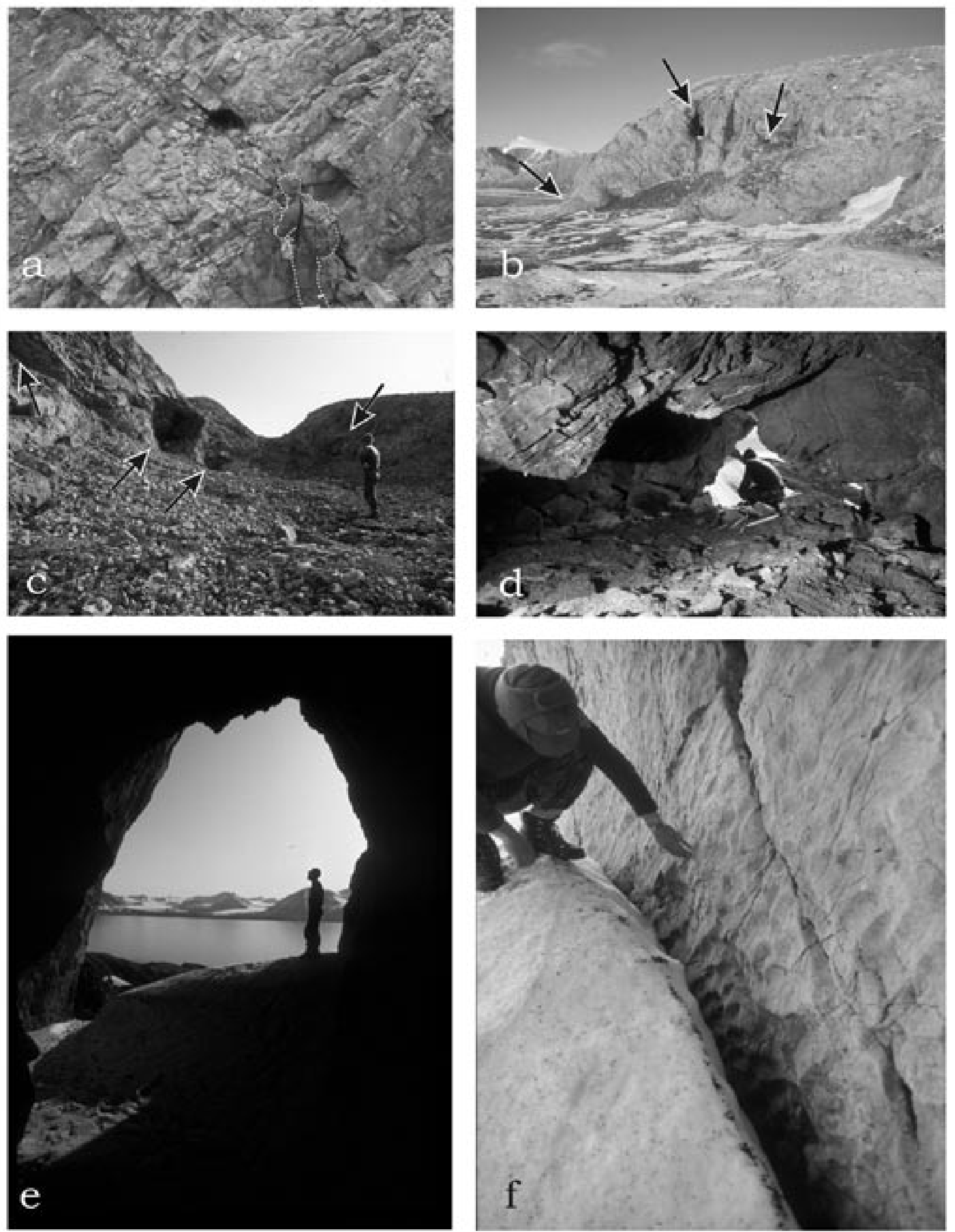

Fig. 12. Relict karst caves. a) Small phreatic tube (C2), Grottebekken. b) Steep escarpment of Bratlikollen, adjacent to strandflat (left arrow). From left, the portal of G5 and the smaller entrance of G4. c) North end of Bogaz II, camera facing S. Apex knickpoint with caves, left G3a..c, right arrow. G2. d) Interior of G4, showing cryoclastic fragments and red cave soil. e) Entrance profile of Portalgrotta (G5), mountains surrounding Ny-Ålesund in the distance. Note the smooth cross section, little disturbed by gelifraction. f) Scalloped wall in entrance of G5. Water flow was towards the camera, i.e. into the cave. All Photographs: S.E.Lauritzen. 

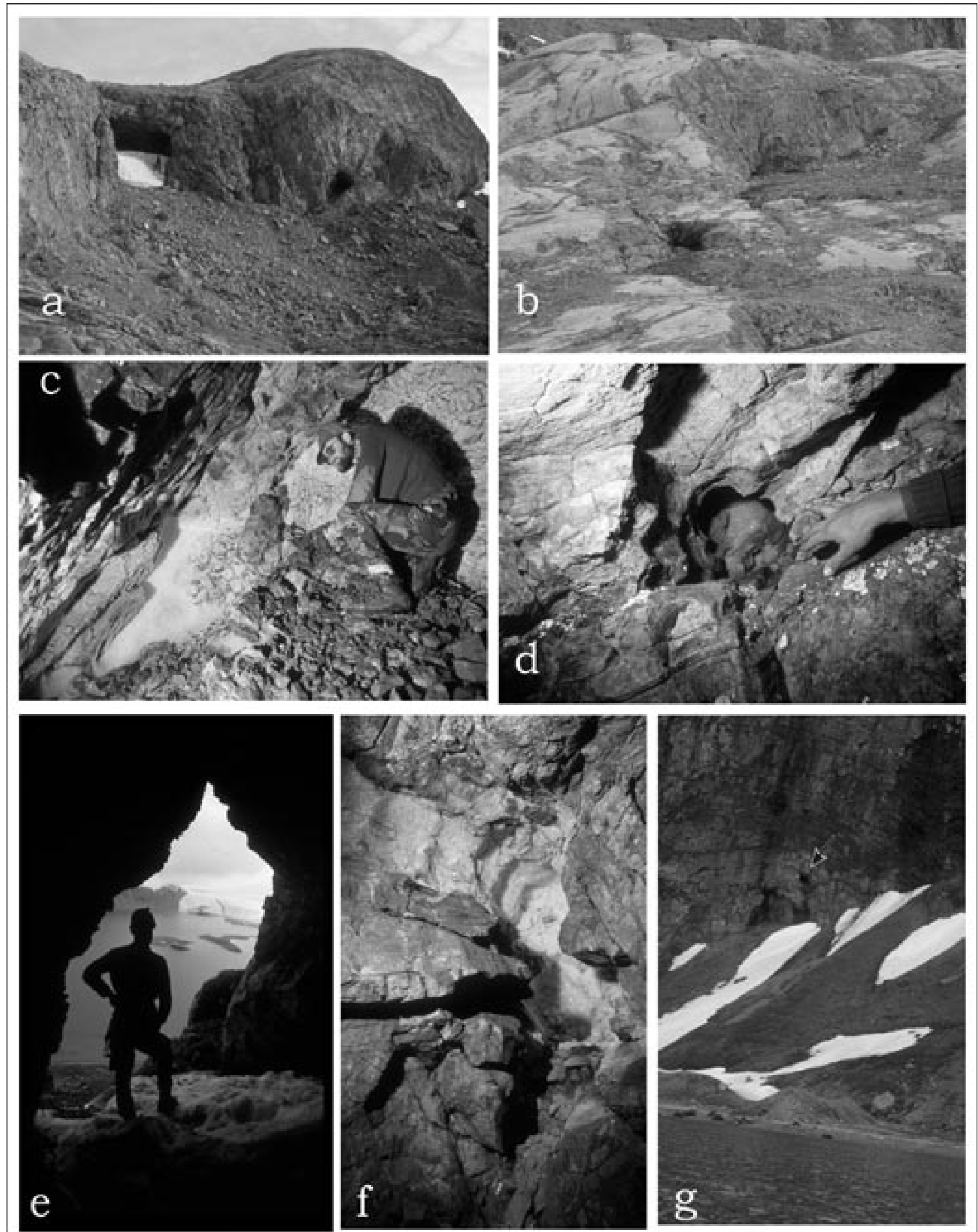

Fig 13. Relict karst caves. a) cave entrances in the lee side of Rundsvaryggen. Left G18, right G17. b) G15 and G16, effluent passages beneath the lee side escarpment of roche moutonnées. Both caves bleed red sediments into the solifluction lobes in front of them. c) terminus of G5, 34 $\mathrm{m}$ from the surface cliff. Ground ice and hoarfrost. d) Phreatic tube continuing as paragenetic ceiling half-tube, G22 (Takrørgrotta). Red-brown diamictic sediment in lower front part of the tube. e) entrance silhouette of G22, at $226 \mathrm{~m}$ a.s.l. overlooking Sørvågen and Blomstrandbreen. f) Ceiling half-tube (with hoarfrosted scallops) continuing into phreatic conduit, G22. g) 'the hole-in-the-wall, entrance to G21, Sørvåggrotta in the northern wall of Irgensfjellet. All photographs: S.E. Lauritzen. 
completely filled calcite vug, Fig. 18. The outline of this vug is quite different from the numerous extentional calcite veins on the island that display parallel (fracture) walls. Here, the sparry calcite has filled an irregular space with bulbous, semicircular outline. Clearly, the host rock must have been corroded prior to filling with calcite, suggesting that this feature is the remnant of an early phase of hydrothermal, hypogene karstification. The calcite vug does not display the common red stains seen in some of the tectonic veins on the western shores of the island.

Most of the relict caves display similar, simple architecture: a main entrance passage leads into the cliff where side passages branch off at right angles. These side passages are almost always parallel with the local cliff face. The corresponding guiding fractures comprise two approximately perpendicular, steeply dipping sets with roughly E-W and N-S strike. This is compatible with the large-scale faulting and bedding attitude seen on the island. It is possible that gravitational or ice-drag stresses have contributed to open fractures parallel with cliff faces, thereby stimulating speleogenesis.

In both sea caves and relict caves, permafrost is encountered after less than $10 \mathrm{~m}$ from the surface, and no penetration was possible beyond $34 \mathrm{~m}$. This is in good accordance with observations in other high arctic, permafrozen areas. Tsi-tche-Han cave in the Yukons appears to penetrate $40 \mathrm{~m}$ horizontally from the outer portal, and $27 \mathrm{~m}$ from the first constriction (Lauriol et al., 2001), Icedam Cave, Alaska penetrates 20+ $m$ (Juday, 1989). Maximum depth of exploration in Yukon is $100 \mathrm{~m}$ horizontally and $50 \mathrm{~m}$ vertically (B. Lauriol, p.c.).

\section{Uranium-series dating of speleothems}

Samples were collected from G21, Sørvåggrotta and from G27, Kronegrotta. In G21, a piece of frostshattered wall flowstone was taken, and in G27, the cemented gravel was dated. Sample G21 is a massive, dense flowstone crust, some $3 \mathrm{~cm}$ thick, which was dated in bulk using alpha particle spectrometry, Table II. Samples were prepared according to standard procedures (Ivanovich and Harmon, 1992), and processed by tailored software (Lauritzen, 1993).The G21 sample dated to $34.2 \pm 1.9 \mathrm{kyr}$. The measured ${ }^{230} \mathrm{Th} /{ }^{232} \mathrm{Th}$ activity ratio is 11 , indicating that the sample was contaminated with non-authigenic ${ }^{230} \mathrm{Th}$ at the time of deposition, resulting in an apparent age that is too high.

This contamination can be modeled (Schwarcz, 1980; Richards and Dorale, 2003) using an 'earth mean' initial ${ }^{230} \mathrm{Th} /{ }^{232} \mathrm{Th}$ activity ratio $\left(\mathrm{B}_{0}=1.5\right)$, which yields a corrected age of $30.5 \pm 2.06$ kyr. From the isochron regression (vide infra), a local $\mathrm{B} 0=0.40$ can be worked out for the carbonate cement in G27, using this as a correction factor, yields a corrected age for the G21 flowstone at $33.2 \mathrm{kyr}$ (large errors), which suggests that the estimate of $31-33 k y r$ is relatively robust.
The cemented gravel bank was dated by the isochron technique using successive leaching with acids of increasing strength (Table III). These results were then plotted as Broecker isochrons, the slope of which yields the uncontaminated values of activity ratios ${ }^{230} \mathrm{Th} /{ }^{234} \mathrm{U}$ and ${ }^{234} \mathrm{U} /{ }^{238} \mathrm{U}$ (Schwarcz and Blackwell, 1992). These values (Fig. 19) convert to an age of $23.9 \pm 5.8 \mathrm{kyr}$. Both ages fall within a known, relatively warm period in Svalbard, the Kapp-Ekholm interstadial (50- $25 \mathrm{kyr}$, Mangerud \& Svendsen op. cit.) and is compatible with the idea that speleothems that are fed by meteoric water would grow preferably under interstadial or interglacial periods when soil respiration and water circulation may take place, e.g. (Lauritzen, 1995).

\section{SPELEOGENESIS}

\section{Paleokarst phases}

Possibly the earliest trace of karstification is the calcite vug in G29. This phase was probably earlier than the later, well-documented Devonian

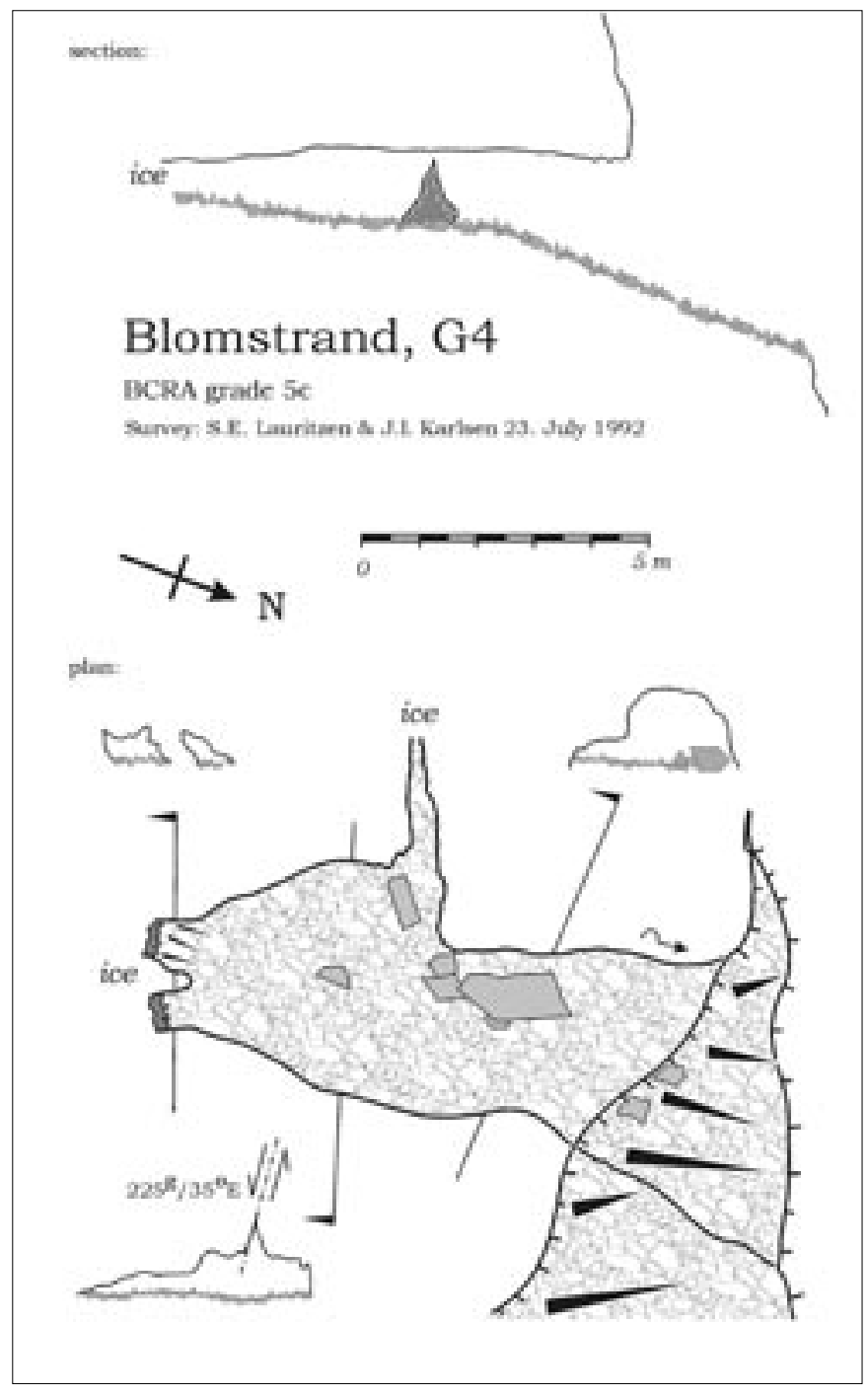

Fig. 14. Cave 4, located in Grotteveggen adjacent to the Bogaz II of Fig. 9. Note the effluent scallops at the western wall. Symbols as in Fig. 9; crossed shading is snow or perennial ground ice. Arrow with hook: scallops and inferred flow direction. 


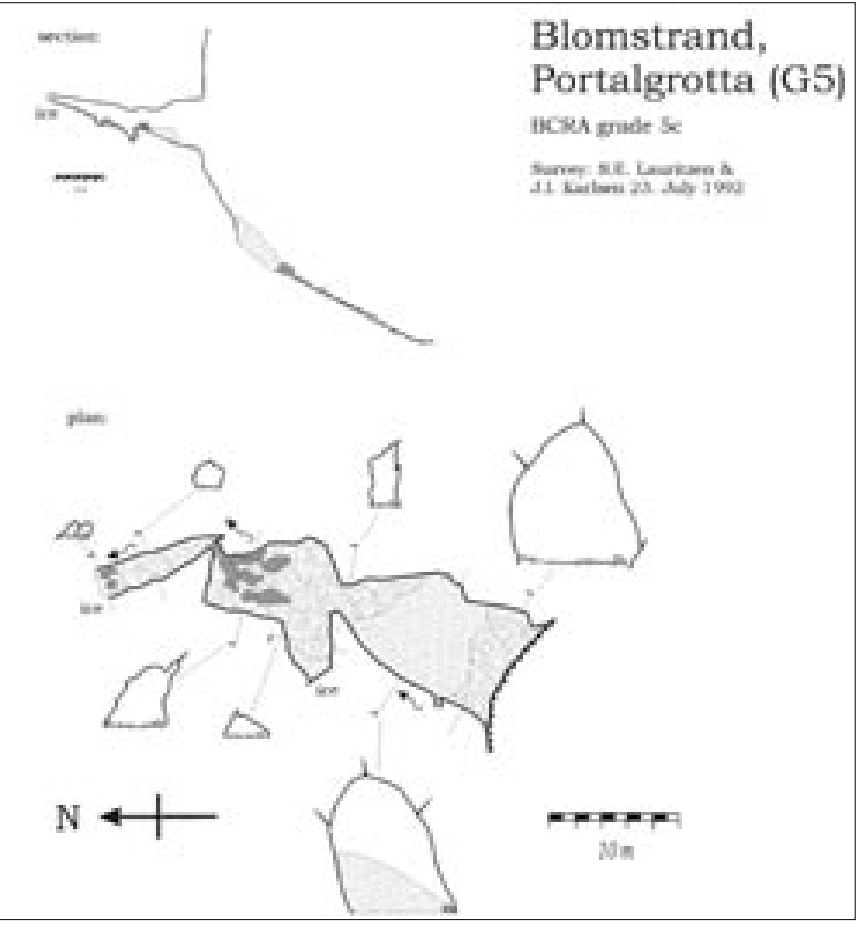

Fig. 15. Portalgrotta (G5), the most prominent and largest cave in Grotteveggen. This is the 'deepest' cave found so far, penetrating $32 \mathrm{~m}$ from the cliff wall, before the passage terminates in frozen sediments and ground ice. Note the influent scallop flow direction and the arched cross sections.

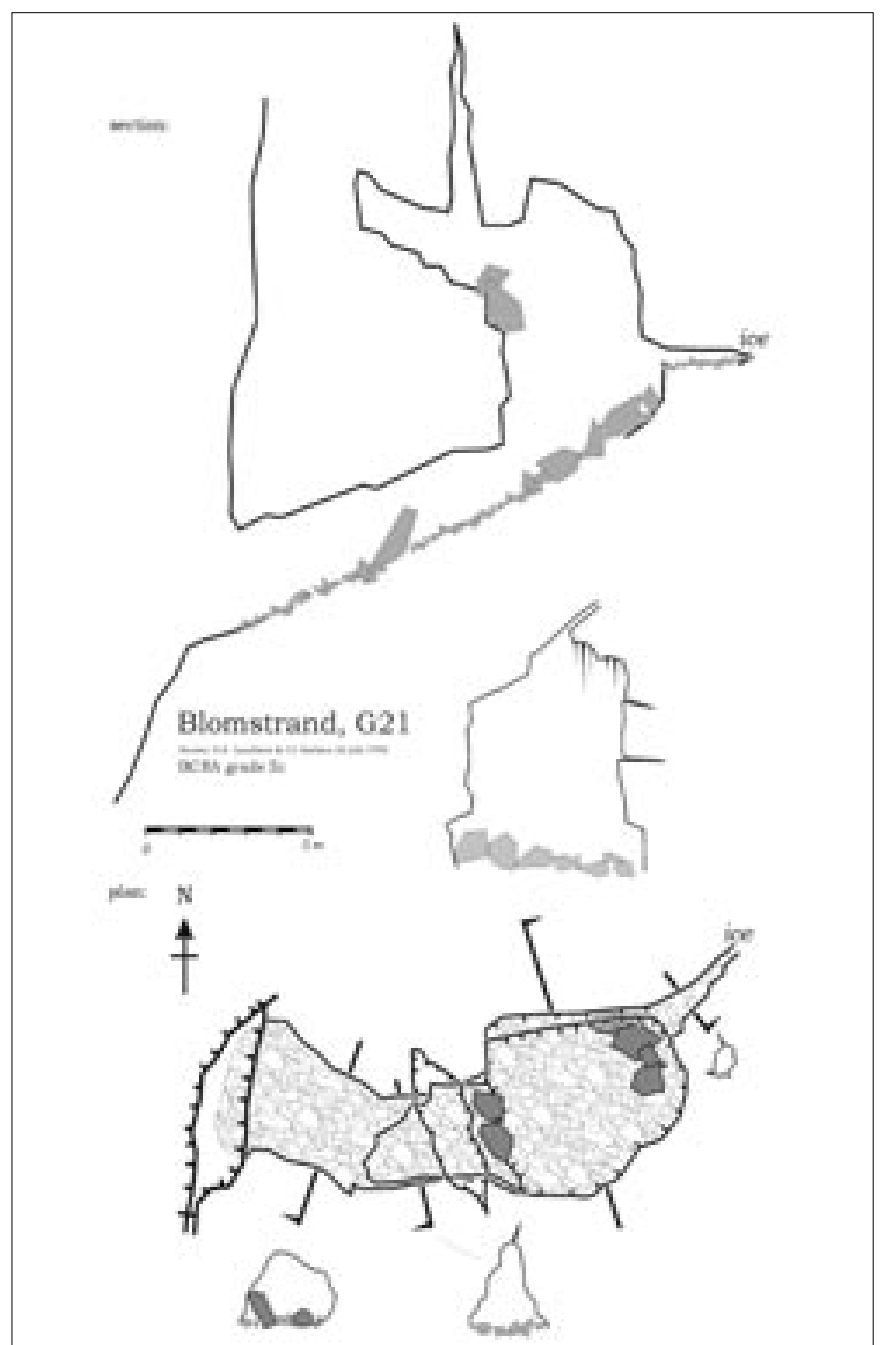

Fig. 16. Sørvåggrotta (G21, or 'The-Hole-in-the-wall') in the NW face of Irgensfjellet.

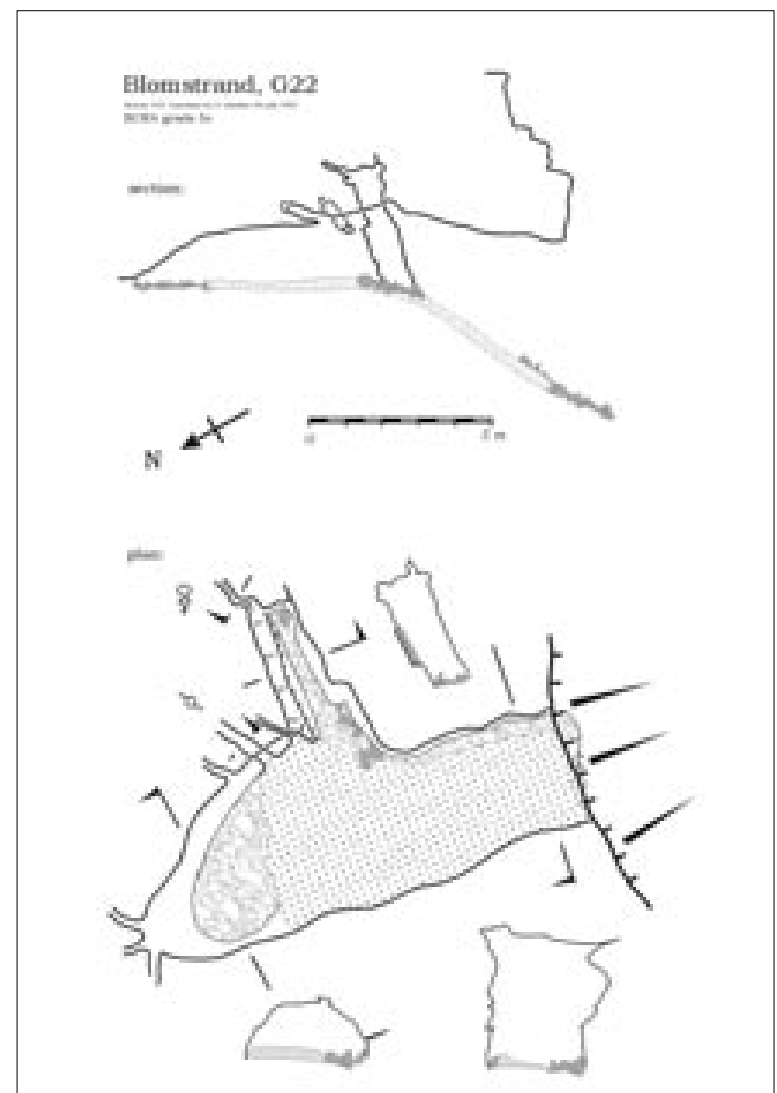

Fig. 17. Takrørgrotta (G22), a cave with well- developed and scalloped half-tubes in walls and ceiling. Northern face of Brattlikollen.

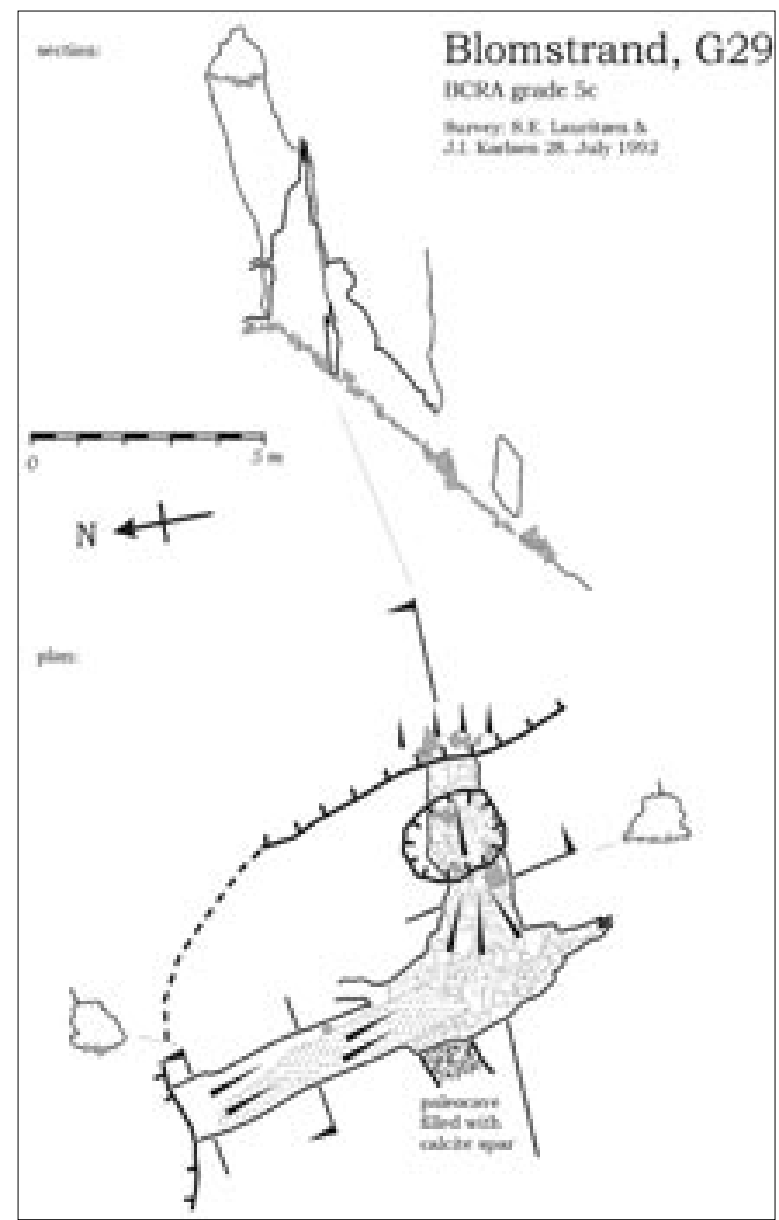

Fig. 18. Termalgrotta (G29), a fissure cave with rounded corrosion vugs filled with hydrothermal calcite. Northern slope of Irgensfjellet. 


\section{Cement, G-27}
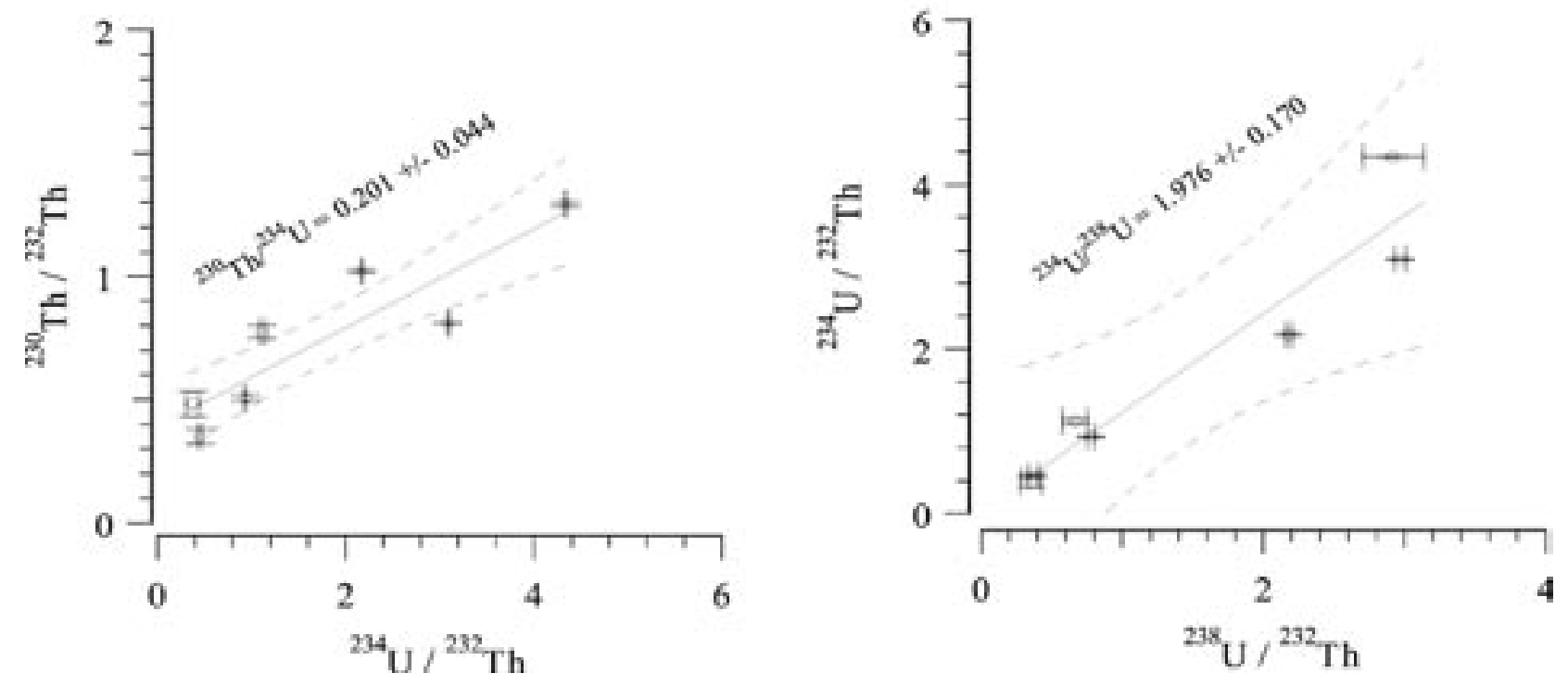

Fig. 19. Broecker isochrons for the calcite cement in G22. See text for further discussion.

karstification. The Devonian karst phase is associated with many deposits of redbed fines. Thiedig \& Manby op. cit. also claim these deposits to be arranged radially out from the center of the island, suggesting that it was a topographic high also in the Devonian. These paleokarst channels and infills have later been eroded and intersected by Quaternary glaciation.

\section{Caves}

In the following, when we discuss the speleogenesis of the numerous relict caves described, we shall assume that the speleogenetic agents that operated in one site, also could operate in other sites, although not necessarily at the same time. It is tempting - but probably wrong - to assume that the last time favourable conditions and agents were available was also the time when they were actively forming the caves. Only dating and independent evidence may solve this question, so one is often restricted to link speleogenetic facies (Lauritzen and Lundberg, 2000) to conditions and agents rather than timing. It must also be kept in mind that all these objects are incompletely known fragments, obscured by frozen sediments. Their total extent is unknown and presently beyond observation. Therefore, the observed cave 'entrances' might either be all there is, or they might be former entrances into much more extensive conduits that are filled with ice and frozen sediments. Here, wall scalloping, combined with hydraulic continuity, provide crucial independent evidence for continuation. A scalloped passage fragment which displays a definite flow direction has indeed transported water from one point in space to another and must therefore be regarded as a conduit. If we can reject the possibility that the passage in question was a mere rock-mill (eddy), then it follows that the conduit must have a continuation beyond the frozen fill, into the rock mass. On the contrary, if there is no apparent continuation, like in the sea caves, we have to invoke speleogenetic agents acting on the surface with only limited penetration abilities. Another limitation is that scallops - and other speleogenetic facies sculptured into cave walls- only represent the last time slice of the cavity's evolution. A scallop pattern, which generally has a relief of $10-30 \mathrm{~mm}$, would as a minimum, require from some $10^{2}$ to $10^{3}$ years to form and erase any previous pattern.

\section{Formation of sea caves}

With very few exceptions, all observed sea caves are located up to about $5 \mathrm{~m}$ a.s.1. in cliff faces that are actively eroding today $(10 \mathrm{~m}$ if we include all blowholes). In spite of being in contact with the marine talik, none of them are very deep. As mentioned, they are of two types, either short, broad chambers with arched cross sections, or elongated, fissure-guided passages with tall and narrow cross sections. The difference between the two types seem linked to the attitude of guiding fractures (Figs. $10 \& 11$ ). The caves end either in solid rock, sometimes frozen, or in shingle beaches. The altitude distribution of all caves, including sea caves, is depicted in Fig. 20. Of these, the sea caves outnumber all other caves, and they are (of course) clustered in the interval $[-5 . .+10]$ $\mathrm{m}$ a.s.1. When compared to the postglacial sea level curve (Fig. 4), there is a striking similarity between the number of sea caves and the relatively constant sea level since $9.5 \mathrm{kyr}$. The number of caves and the time post-glacial sea level has spent at various levels correlate, and (relict) caves occur at much higher levels than any known former sea level. This does not necessarily mean that all caves are sea caves (vide 
infra), but it strongly suggests that the large number of active sea caves are indeed connected to the presentday sea-level and processes active in the littoral zone. It is also possible that some of the sea caves may have originated from pre-existing karst conduits or karstified zones of weakness.

Most of the sea caves in Blomstrandsøya face open, deep water in the fjord, Fig. 21. This trend is also evident when one looks at the number of caves per $\mathrm{km}$ of rocky coastline. Also, the largest caves invariably face open deep water. This strongly suggests that wave energy was important in their formation, either in the form of direct breakers (e.g. blowholes), or by disintegrating and moving gelifracted erosion products into deeper water. Sea caves in non-karstic rocks are often formed along zones of weakness (fractures) by frost shattering, combined by 'wrenching' effected by ice rafts and tidal cycles, e.g. (Aarseth and Fossen, 2004a, b). Moreover, wave breakers cause enormous pressures and cavitation as well as moving large boulders forth and back in a rock-mill like fashion.

The rate of frost-weathering under arctic coastal conditions can get quite high. André (1998) quotes that for strongly fractured sites in Spitsbergen, gelifraction rates may exceed $1-3 \mathrm{~mm}$ yr -1 . Under similar, arctic

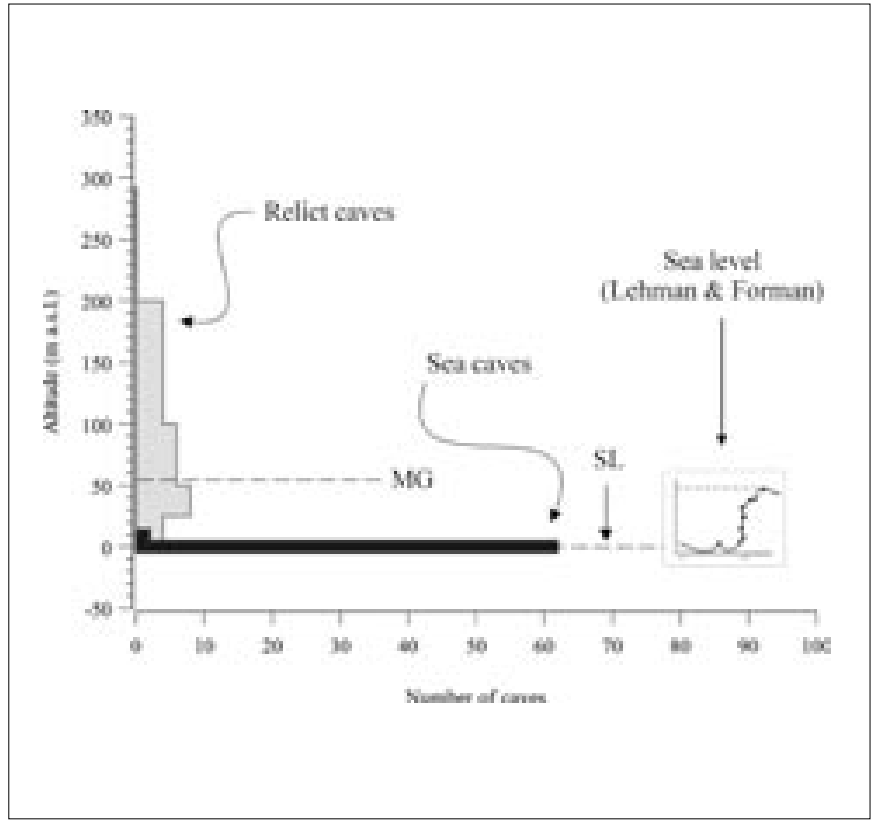

Fig. 20. Frequency distribution of cave levels in Blomstrandsøya, divided into active seacaves (black) and relict caves (grey shade). $\mathrm{SL}$ : present-day sea level, MG: late-glacial marine limit at Brøggerhalvøya extrapolated $(1.5 \mathrm{~m} / \mathrm{km})$ to Blomstrandsøya. Inset to the right: the cave distribution is compared with the sea level curve from Lehman \& Foreman, i.e. Fig. 5.

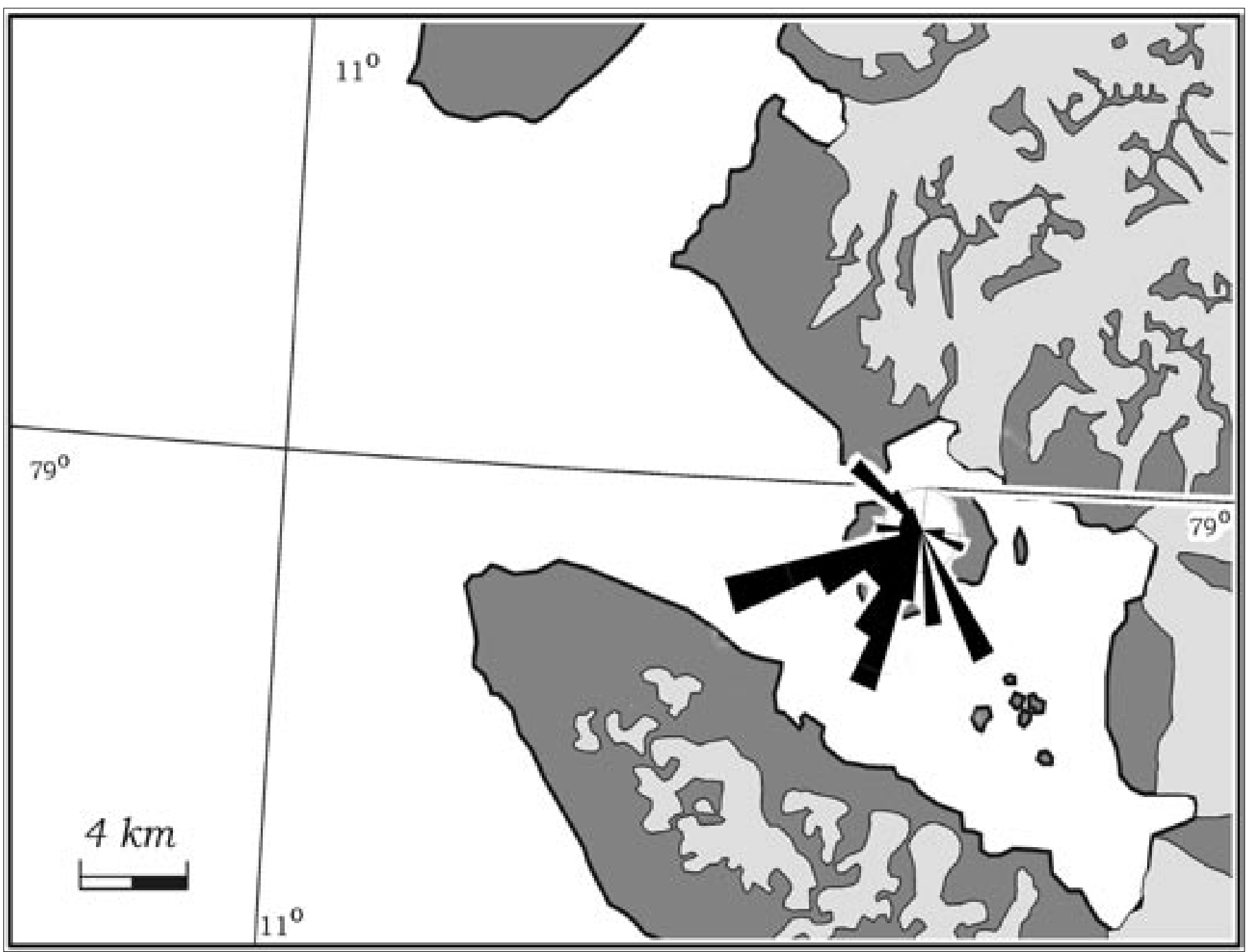

Fig. 21. Exposure aspects of 62 sea caves at or $<10 \mathrm{~m}$ above present-day sea level in Blomstrandsøya. $94 \%$ of these caves face open, deep sea in the fjord where wave abrasion would be optimal. 


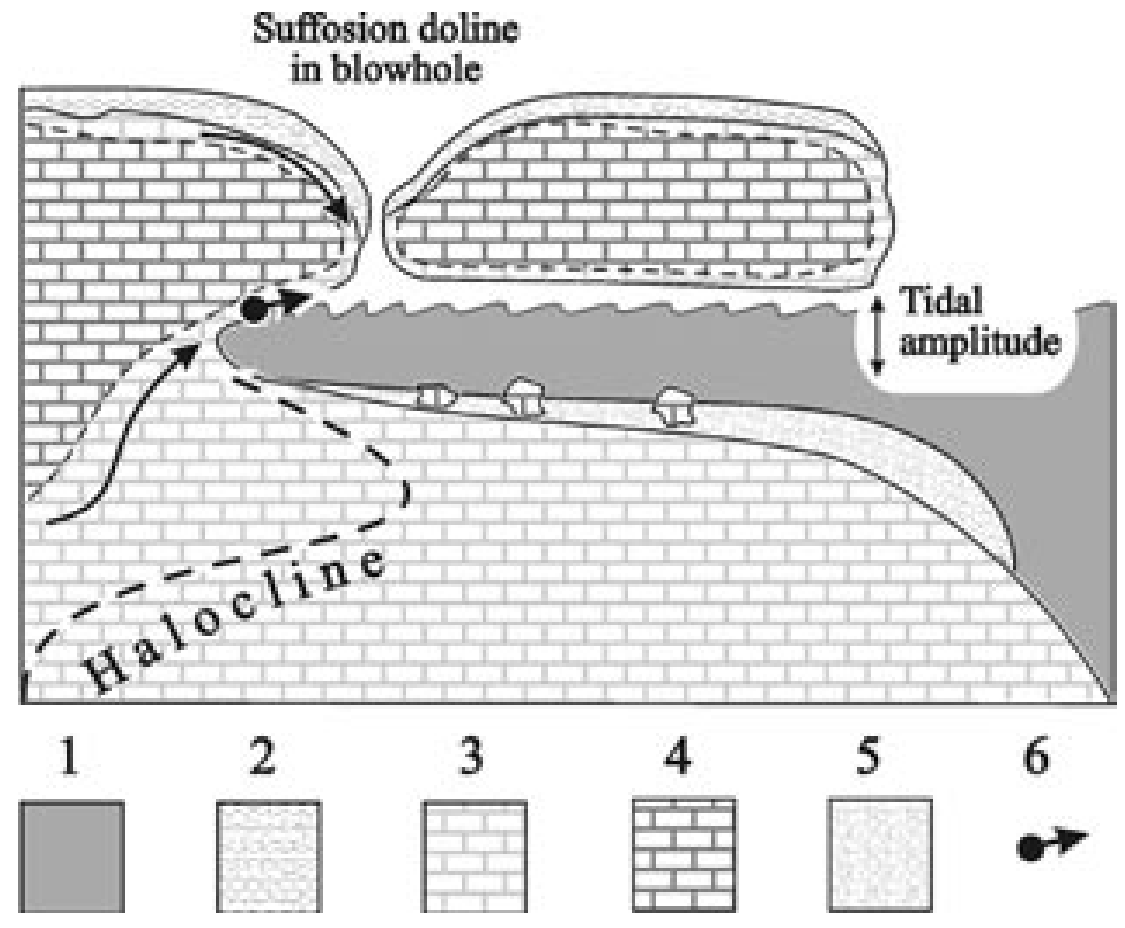

Fig. 22. Conceptual model of a karstic seacave formation in conjunction with permafrost. See text for further discussion. Legend: 1: seawater, 2: cryoclastic regolith and glacial drift. 3: unfrozen limestone. 4: Frozen limestone. 5: beach shingle and gravel. 6: hypothetical outflow of subpermafrost groundwater. After Lauritzen (1998).

and moist conditions, like during the Younger Dryas at the northern Norwegian coast and at present-day alpine lakeshores, much higher rates have been reported, e.g. 40 mmyr-1; (Rasmussen, 1981), and 27 mm yr-1; (Matthews et al., 1986). Aarseth $\&$ Fossen (2004a) estimated a rate of $1 \mathrm{~mm}$ yr-1 for Holocene cryoplanation of a lakeshore. Given the relatively small dimensions of the sea caves of Blomstrandsøya, the rates of frost weathering and the time that sea level stayed the same, strongly suggest that most of, if not all, observed sea caves may be explained by coastal gelifraction processes acting in the Holocene.

Since the host rock is karstic, solution may play a significant additional role in sea cave formation. The marine talik is a zone of confluence for supra- and subpermafrost groundwater flow. This is seen in Jakobskjelda (vide supra) and in the talik dolines described by Salvigsen \& Elgersmaa (1985). Moreover, we may also anticipate a saltwater wedge, penetrating the thawed, fissured rock beneath sub-permafrost water, forming a hypothetical halocline. Theoretically, corrosion processes associated with the mixing of freshwater and seawater may contribute to open fractures in much the same way as halocline caves are formed in carbonate islands (Mylroie and Carew, 1988). Therefore, we may propose a model for sea cave formation in a permafrozen, karstic coast which includes all observations and synergy of the processes discussed above, Fig. 22.

\section{Formation of relict caves}

a) Possible origin from marine erosion or frostpocketing

Provided that the caves terminate just beneath the cover of cryoclastics and red earth, they would all be similar to the active sea caves, i.e. pockets of limited extent where the speleogenetic agents must have worked inwards from the surface of the cliff faces. However, the cave locations seem rather randomly distributed in space and there is no evidence of any additional level-controlled erosion around them. If the relict caves originated as sea caves, developed with the same process intensity as the present ones do, we should expect them to occur at distinct levels, 
independent of geological structure and they should be associated with remnants of erosional notches, etc. This distinguishes them from the sea caves, which are vertically clustered and located in the cliff faces of the prominent strandflat.

The relict caves are less diverse in outline than the sea caves, they are more branched and none of them display the wide, arched features seen in Fig. $10 \&$ 11. Only one (G5) out of 30 cave entrances displays any pronounced widening towards the surface, which may indicate modification by marine eroding agents. However, seacave walls are faceted by frost shattering; occasionally, they may display polished surfaces adjacent to the shingle beaches, but these surfaces lack scalloping. The entrance of G5 is completely different, it is large, but smooth and solutional. It bears scallops and displays only slight gelifraction.

There is, of course, a remote possibility - which we cannot rule entirely out - that the relict caves may be so old that former marine features have been eroded away. It seems much more likely that the relict, dry caves are of a different class with a different origin, being formed by relatively recent processes. It is, for the same reasons, likely that the present sea caves may include some modified versions of this class.

\section{b) Origin as subglacial karst conduits}

Scalloping and the principle of hydraulic continuity strongly suggests that the passages were indeed part of conduits that transported water through the rock mass, beyond the limit of human exploration. This water transport occurred at all observed levels, up to about $290 \mathrm{~m}$ a.s.1., and must have operated under partial or totally unfrozen conditions. In order to invoke taliks of this kind, we may either raise sea level up to or above the caves, or we may cover the caves under thick ice. The late glacial marine limit, extrapolated to Blomstrandsøya, is slightly above $50 \mathrm{~m}$ a.s.1. This is however the highest recorded sea level; sea level could have been much higher during the stadials without leaving any trace. However, even if glacial sea levels exceeded the level of our caves, they would then be situated beneath a thick ice cover and the marine contact would be tens of kilometres away. Internal ice sheet hydraulics would then determine and dominate the local water table, and the water would be fresh. Older, and presumably higher sea levels therefore seem irrelevant for speleogenesis as long as a thick ice sheet was present.

The observed scallop directions may at the first glance seem contradictory, as neighbouring caves (G4 and G5) transported water in opposite directions. First, this might not have occurred at the same time, nor is reversal of flow contradictory with glacier hydraulics. In a subglacial situation, Blomstrandsøya would be situated at the confluence between several ice-streams, of which the two important ones are the main flow from the southeast through Kongsfjorden and the stream emerging from the east via Sørvågen from the mountains behind Blomstrandsbreen, Fig. 3. Therefore, hydraulic gradients through the northern part of Blomstrandsøya would alternate between east to west and west to east, as well as south to north, depending on the relative magnitude of the two ice streams at any time. Subglacial water flow is dictated more by the surface slope of the glacier than on the underlying bedrock topography. Forced-flow, subglacial speleogenesis is well known, e.g. (Lauritzen, 1986; Ford and Williams, 1989). This mechanism could accommodate the observed scallop directions in all caves investigated. Second, the unequivocal paragenetic features observed are also fully compatible with subglacial karstification. The large portal of G5 may also be explained as a paragenetic feature. Third, the bogaz forms are also aligned according to the hydraulic conditions deduced above. They would have functioned as efficient N-channels, although at different times. Fourth, the whaleback ridges with associated caves (G15\&16) accommodated ice flow from east to west; G17 and G18 would also be effluent under these conditions.

The speleothem dates provide direct evidence that the caves existed prior to the last Weichselian glaciation, that they were drained above sea level during the Kapp Ekholm Interstadial, and that at least part of the sub-glacial speleogenesis took place during earlier stadials in the Quaternary.

\section{c) Pre-glacial speleogenesis}

As suggested for Irgenstjernet, products of preglacial or Tertiary karst processes may be preserved. Several of the relict caves, and maybe some of the sea caves as well, are located adjacent to redbed paleokarst inliers, and they are guided by the same faults. There is no doubt that many of the relict caves contain redbed-derived sediments, either as a primary deposit, or as secondary deposits, eroded from redbeds elsewhere. Therefore, the present caves could then be viewed as paleokarst conduits that are reactivated and considerably widened (speleogenesis sensu lato) by Quaternary processes and we cannot exclude that speleogenesis of the presently known relict caves commenced in the Tertiary. In fact, since karstification is a continuous process, lacking intrinsic thresholds, it is unlikely that meteoric speleogenesis did not commence in near-surface locations during the Tertiary.

\section{CONCLUSIONS}

Contrary to the opinions of previous workers, a surprisinglylargenumber of relictcaves have beenfound and described in addition to an even larger amount of active sea caves. Most of the relict caves can be explained by glacier ice contact and sub-glacial processes. The present author suggests subglacial speleogenesis as the dominant process. U-series dating prove that 
some of the relict caves are at least older than the last Weichselian glaciation. The rapid uplift and subsequent constant sea-level during the Holocene is exceptional for most karst areas that have experienced glacio-isostatic rebound. Thus, Holocene processes alone can explain most of the volume in the sea caves. Consequently, if the sea caves were originated in previous interstadial or interglacial periods, those periods need to have had a sea level similar to the Holocene.

\section{A speleogenetic model for Blomstrandsøya}

The speleogenesis of the caves may be summarised as follows:

\begin{tabular}{|c|c|c|}
\hline & Phase & Possible timing \\
\hline 1 & $\begin{array}{l}\text { Hypogean, hydrothermal } \\
\text { karstification and subsequent } \\
\text { infilling with calcite. }\end{array}$ & $\begin{array}{l}\text { Caledonian or later, but pre- } \\
\text { Devonian. }\end{array}$ \\
\hline 2 & $\begin{array}{l}\text { Devonian (?) karstification } \\
\text { and tectonics with redbed } \\
\text { infilling. }\end{array}$ & Post-Caledonian (Devonian) \\
\hline 3 & $\begin{array}{l}\text { Pre-glacial commencement } \\
\text { of present-day caves, in } \\
\text { part reactivating paleokarst } \\
\text { conduits }\end{array}$ & Tertiary? \\
\hline 4 & $\begin{array}{l}\text { Subglacial speleogenesis } \\
\text { under various extents of ice } \\
\text { cover, formation of scalloped } \\
\text { conduits, often under } \\
\text { paragenetic conditions }\end{array}$ & Quaternary \\
\hline 5 & $\begin{array}{c}\text { Post- and interglacial } \\
\text { obstruction and freezing of } \\
\text { caves. }\end{array}$ & Quaternary \\
\hline 6 & $\begin{array}{c}\text { Intensive, postglacial } \\
\text { marine erosion, in some } \\
\text { cases invading pre-existing } \\
\text { paleokarst and subglacial } \\
\text { caves. }\end{array}$ & Holocene and interglacial \\
\hline
\end{tabular}

\section{Further work}

In order to test the hypotheses outlined in this paper, the sea caves need to be fully explored above and under water and surveyed accurately in order to obtain more precise morphological information. In this way, one may perhaps be able to observe and sample the hypothesised sub-permafrost groundwater flow. The potential for finding more and interesting relict caves in the steep cliffs is by far not exhausted, and stratigraphic investigations of cave fills is also needed. Further work on Blomstrandsøya and adjacent areas in the Hecla Hoeck marbles is in progress.

\section{ACKNOWLEDGEMENTS}

Field work in 1991, 1992 and 1997 was financially supported by The Norwegian Hydrological Committee (NHK) and by the Norwegian Research Council (NFR). Norsk Polarinstitutt (NP) is thanked for logistic support. Jan Inge Karlsen assisted in the field. Narve Ringset is thanked for providing the photograph in Fig. 4b. Margaret Palmer, Alexander Klimchouk and Jan Mangrud are thanked for constructive comments. Bernard Lauriol provided data on exploration limits in the Yukons.

\section{REFERENCES}

Aarseth, I., Fossen, H. 2004a - A Holocene lacustrine rock platform around Storavatnet, Osterøy, western Norway. The Holocene 14: 589-596.

Aarseth, I., Fossen, H. 2004b - Late Quaternary, cryoplanation of rock surfaces in lacustrine environments in the Bergen area, Norway. Norsk Geologisk Tidsskrift 84: 125-137.

André, M.F. 1998 - Holocene rockwall retreat in Svalbard: A triple-rate evolution. Earth Surface Processes and Landforms 22: 423-440.

Brown, R.J.E. 1970 - Permafrost in Canada University of Toronto Press, Toronto.

Corbel, J. 1957 - Les karts du Nord-oest de l'Europe et de quelques regions de comparison. Institute des Etudes Rhodanniennes. Memoires 12: 1-541.

Davies, W.E. 1960 - Caves in Northern Greenland. National Speleological Society, Bulletin 22: 114-116.

Deming, D., Sass, J.H., Lachenbruch, A.H., De Rito, R.F. 1992 - Heat flow and subsurface temperature as evidence for basin-scale ground-water flow, North Slope of Alaska. Geological Society of America Bulletin 104: 528-542.

Dixon, E.J., Heaton, T.H., Fifield, T., Hamilton, T.D., Putnam, D.E., Grady, F. 1997 - Late Quaternary regional geoarchaeology of Southeast Alaska karst: A progress report. Geoarchaeology 12: 689-712.

Ford, D.C. 1984: Karst groundwater activity and landform genesis in modern permafrost regions of Canada. pp. 340-350 In: LaFleur, R.G., (Ed.) Groundwater as a Geomorphic Agent. Allen \& Unwin, New York.

Ford, D.C., Williams, P.W. 1989 - Karst geomorphology and Hydrology Unwin Hyman, London. 601 pp.

Glazek, J., Rudnicki, J., Szynkiewicz, A. 1977 - Proglacial caves- a special genetic type of cave in glaciated areas. Proceedings, 7th. International Speleological Congress, Sheffield 1: 215-217.

Haldorsen, S., Lauritzen, S.E. 1993 - Subpermafrost groundwater in Svalbard. Hydrogeology of Hard Rocks. 26th Congress of the International Association of Hydrogeologists 2: 940-949.

Hjelle, A. 1979 - Some aspects of the geology of northwest Spitsbergen. Norsk Polarinstitutt skrifter 167: 37-62.

Holtedahl, H. 1996 - The Norwegian Strandflat - a geomorphological puzzle. Norsk Geologisk Tidsskrift 78: 47-66. 
Horn, G. 1935 - Über die Bildung von Karsthöhlen unter einem Gletcher. Norsk Geografisk Tidsskrift 5: 494-498.

Horn, G. 1947 - Karsthuler i Nordland. Norges Geologiske Undersøkelse 165: 1-77.

Horn, G. 1978 - Limestone Caves in Nordland. Cave Geology 1: 124-138.

Ivanovich, M., Harmon, R.S. 1992 - Uranium-series Disequilibrium: Applications to Earth, marine, and Environmental Sciences Clarendon Press, Oxford. 910 pp.

Juday, G.P. 1989 - Alaska Research Natural Areas. 2: Limestone Jags United States Department of Agriculture. Forest Service, Washington DC. 58 pp.

Lauriol, B., Prévost, C., Deschamps, E., Cinq-Mars, J., Labrecque, S. 2001 - Faunal and Archaeological Remains as Evidence of Climatic Change in Freezing Caverns, Yukon Territory, Canada. Arctic 54: 135-141.

Lauritzen, S.E. 1986 - Kvithola at Fauske; Northern Norway: an example of ice- contact speleogenesis. Norsk Geologisk Tidsskrift 66: 153-161.

Lauritzen, S.E. 1991: Groundwater in Cold Climates: Interaction Between Glacier and Karst Aquifers. pp. 139146 In: Gjessing, Y., Hagen, J.O., Hassel, K.A., Wold, B., (Eds.) Arctic Hydrology. Present and Future Tasks, Hydrology of Svalbard - Hydrological problems in cold climates. Norwegian National Commitee for Hydrology, Oslo.

Lauritzen, S.E. 1993: "Age4U2U”. Program for reading ADCAM energy spectra, integration peak-correction and calculation of ${ }^{230}$ Thorium/ ${ }^{234}$ Uranium ages. Computer Program Turbo Pascal Code, 5,000 lines, Department of Geology, Bergen.

Lauritzen, S.E. 1995 - High-resolution paleotemperature proxy record during the last interglaciation in Norway from speleothems. Quaternary Research 43: 133-146.

Lauritzen, S.E. 1998: Chapter 3: Karst Morphogenesis in the Arctic: Examples From Spitsbergen. pp. 51-72 In: Daoxian, Y., Zaihua, L., (Eds.) Global Karst Correlation. Science Press; VSP International Scientific Publisher, Bejing \& Amsterdam.

Lauritzen, S.E., Lundberg, J. 2000: Meso- and Micromorphology of Caves: Solutional and erosional morphology. pp. 407-426 In: Klimchouk, A., Ford, D.C., Palmer, A.N., (Eds.) Speleogenesis: Evolution of Karst Aquifers. National Speleological Society, Huntsville, Ala.

Lehman, S.J., Forman, S.L. 1992 - Late Weichselian lacier Retreat in Kongsfjorden, West Spitsbergen, Svalbard. Quaternary Research 37: 139-154.

Liestøl, O. 1976 - Pingos, springs and permafrost in Spitsbergen. Norsk Polarinstitutt Årbok 1975: 7-29.

Liestøl, O. 1980 - Permafrost Conditions in Spitsbergen Department of geography, Oslo. 20 pp.

Loubiere, J.F. 1987 - Observations Preliminaires sur les Cavites de la Region du Lac Centrum (Nord-Oest Groenland). Karstologia 9: 7-16.

Mangerud, J., Svendsen, J.I. 1992 - The last interglacialglacial period on Spitsbergen, Svalbard. Quaternary Science Reviews 11: 633-664.
Mangerud, J., Dokken, T., Hebbelin, D., Heggen, B., Ingólfsson, O., Landvik, J.Y., Mejdahl, V., Svendsen, J.I., Vorren, T.O. 1998 - Fluctuations of the Svalbard- Barents Sea ice sheet during the last 150000 years. Quaternary Science Reviews 17: 11-42.

Matthews, J., Dawson, A.G., Shakesby, R.A. 1986 - Lake shoreline development frost weathering and rock platform erosionin an alpine periglacial environment, Jotunheimen, southern Norway. Boreas 15: 33-50.

Mylroie, J.E., Carew, J.L. 1988 - Solution conduits as indicators of late Quaternary sea level position. Quaternary Science Reviews 7: 55-64.

Nye, J.F. 1965 - The flow of a glacier in a channel of rectangular, elliptic or parabolic cross section. Journal of Glaciology 5: 661-690.

Paterson, W.S.B. 1981 - The Physics of Glaciers Pergamon Press, London. 380 pp.

Price, L.W. 1972 - The Periglacial Environment, Permafrost, and Man Associateion of American Geographers, Washington, D.C. 88 pp.

Rasmussen, A. 1981 - The Deglaciation of the Coastal Area NW of Svartisen, Northern Norway. Norges Geologiske Undersøkelse 369: 1-31.

Richards, D.A., Dorale, J.A. 2003 -Uranium-series Chronology and Environmental Appplications of Speleothems.

Reviews in Mineralogy and Geochemistry 52: 407-460.

Röthlisberger, H. 1972 - Water pressure in intra- and subglacial channels. Journal of Glaciology 11: 177-203.

Salvigsen, O., Elgersmaa, A. 1985 - Large scale karst features and open taliks at Vardeborgsletta, outer Isfjorden, Svalbard. Polar Research 3: 145-153.

Schroeder, J. 1979: Le dévelopment des grottes dans la région du premier canyon de la riviére Nahanni sud, T.N.O. Canada. Ph.D. Thesis, l'École des Études Supérieures de 1'Université d'Ottawa. Ottawa.

Schwarcz, H.P. 1980 - Absolute age determinations of archaeological sites by uranium dating of travertines. Archaeometry 22: 3-24.

Schwarcz, H.P., Blackwell, B.A. 1992: Archaeological applications. pp. 513-552 In: Ivanovich, M., Harmon, R.S., (Eds.) Uranium-series Disequilibrium: Applications to Earth, marine, and Environmental Sciences. Clarendon Press, Oxford.

Thiedig, F., Manby, G.M. 1992 - Origins and deformation of Post-Caledonian sediments on Blomstrandhalvøya and Lovénøyane, nothwest Spitsbergen. Norsk Geologisk Tidsskrift 72: 27-33.

Walder, J., Hallet, B. 1979 - geometry of former subglacial water channels and cavities. Journal of Glaciology 23: 335346.

Werenskiold, W. 1953 - The extent of frozen ground under the sea bottom and glacier beds. Journal of Glaciology 2: 197-200. 
Table I. Karst caves above sea level

\begin{tabular}{|c|c|c|c|c|}
\hline Name & Location and description & Length $(\mathrm{m})$ & Depth (m) & Alt. (m) \\
\hline Grotteelv C1 & $\begin{array}{l}\text { Small cave filled with cryoclastic material in Grotteelva canyon. } \\
\text { Plugged with ice after } 2 \mathrm{~m}\end{array}$ & 2 & 1 & 125 \\
\hline Grotteelv C2 & Sloping passage, $0.3 \mathrm{~m}^{2}$, cryoclastic debris and ice plug & 4 & 1 & 130 \\
\hline Grotteelv C3 & Phreatic tube in canyon cliff, trends $22 \mathrm{~g}$, soil and cryoclastics & 2 & 0.5 & 140 \\
\hline Grotteelv C4 & Small cave sloping upwards, filled with cryoclastics. Trends $105 \mathrm{~g}$. & 2 & 0.5 & 140 \\
\hline C5 & Small cave with water-table and ice & 1.5 & 0.3 & 63 \\
\hline G1 & Cave at SE end of Bogaz & 2 & 0.3 & 35 \\
\hline G2 & Small tunnel cave in Bogaz & 2.5 & 1 & 45 \\
\hline G3a & Small rock-bridge with vertical opening. $\mathrm{N}$ wall of Bogaz & 2 & 1 & 62 \\
\hline G3b & Cave filled with cryoclastics from bogaz, with scalloped ceiling & 1 & 0 & 52 \\
\hline G3c & Small phreatic tube in bogaz wall, ca $20 \mathrm{~cm}$ diameter & 1 & 0 & 52 \\
\hline G4 & $\begin{array}{l}\text { Fault-controlled tube in S-facing cliff. Effluent scallops. Cryoclastic fill. } \\
\text { Ends in ground ice }\end{array}$ & 11.5 & 1 & 70 \\
\hline G5 Portalgrotta & $\begin{array}{l}\text { Huge portal visible from Ny-Âlesund. Influent scallops. Ends in ice and } \\
\text { frozen debris. }\end{array}$ & 39 & 2 & 72 \\
\hline G5a & Phreatic tube in cliff wall, NW of G5 & & & 72 \\
\hline G6 & Cave entrance beneath snowpatch & & & \\
\hline G7 & Small cave next to $\mathrm{G} 4$ & & & 70 \\
\hline G8 & Filled conduit, $1 \mathrm{~m}$ diameter & 1.5 & & 27 \\
\hline G9, G10, G11 & Cave entraces in cliff face, bleeds old-red derived sediments & & & 42 \\
\hline G14 & Small cave & & & 25 \\
\hline G15 Rundsvagrotte 1 & $\begin{array}{l}\text { Cave below cliff face on lee side of roche moutonnée. Filled with ground } \\
\text { ice after } 3 \mathrm{~m}\end{array}$ & 3 & 1 & 72 \\
\hline G16 Rundsvagrotte 2 & $\begin{array}{l}\text { Cave with weathered scallops, filled with soliflucted soil and cryoclastics. } \\
\text { Lee side of roche moutonnée. }\end{array}$ & & & 72 \\
\hline G17 Fissurgrotta & $\begin{array}{l}\text { 'Quite long' straight passage along fracture, ends in hoarfrost and frozen } \\
\text { sediment fill. }\end{array}$ & 9 & 1 & 60 \\
\hline G18 Dobbeltgrotta & $\begin{array}{l}\text { Branched cave formed along veins of hydrothermal calcite, ceiling hole } \\
\text { (blowhole?) small veins of palygorskite. }\end{array}$ & 15 & 5 & 60 \\
\hline $\begin{array}{l}\text { G21 Sørvåggrotta, } \\
\text { 'The-hole-in-the-wall' }\end{array}$ & $\begin{array}{l}\text { Spectacular entrance in cliff face, vertical aven, tiny spelothems. } \\
\text { Cryoclastic fill and ground ice. }\end{array}$ & 40 & 15 & 77 \\
\hline G22 Takrørgrotta & $\begin{array}{l}\text { Entrance high in } \mathrm{N} \text { cliff of Bratlikollen, facing Breøyane and Nordvăgen. } \\
\text { Filled with ice, snow and hoarfrost. Branched phreatic passages and } \\
\text { paragenetic ceiling tubes with scallops. Remnants of old red -derived } \\
\text { fines on the walls }\end{array}$ & 18 & 4 & 226 \\
\hline G23. Bratlirør I & Phreatic tube in cliff wall, $50-70 \mathrm{~cm}$ diameter & 2 & 0.5 & 229 \\
\hline G24 Bratlirør II & Phreatic tube of similar dimensions as G23 & & & 255 \\
\hline G25 Bratlirør III & $\begin{array}{l}\text { Phreatic cave consisting of several tubes, end in ice chokes. Scalloped, } \\
\text { but ambigious flow direction }\end{array}$ & 8 & 3 & 243 \\
\hline G26 Runderøret & Network of phreatic or paragenetic tubes & & & 246 \\
\hline G27 Kronegrotta & $\begin{array}{l}\text { Short, wide phreatic tube, ending in ice and cryoclastic fill. Wall and ceiling } \\
\text { tubes. Deposits of calcite-semented quartz gravel. }\end{array}$ & 8 & 3 & 263 \\
\hline G28 Buegrotta & $\begin{array}{l}\text { Entrance choked with cryoclastics. No clear solution forms. Curvature of } \\
\text { roof arch suggests a very large cave underneath. }\end{array}$ & 2 & & 172 \\
\hline G29 Termalgrotta & Through cave formed along hydrothermal paleokarst infilling. & 17 & 9 & 215 \\
\hline G30 Temptation cave & $\begin{array}{l}\text { Circular entrance above G27, visible at distance from Sørvågen. } \\
\text { Not explored }\end{array}$ & - & - & $280 ?$ \\
\hline
\end{tabular}


Table II. U-series dating of speleothem G-21 Sørvåggrotta

\begin{tabular}{|l|l|r|l|c|l|l|}
\hline J.no & $U(\mathrm{ppm})$ & \multicolumn{1}{l|}{${ }^{234} \mathrm{U} /{ }^{238} \mathbf{U}$} & ${ }^{230} \mathrm{Th} /{ }^{234} \mathbf{U}$ & ${ }^{230} \mathrm{Th} /{ }^{232} \mathbf{T h}$ & Age (kyr) & Corrected age (kyr) \\
\hline 440 & 0.39 & $2.352 \pm 0.108$ & $0.277 \pm 0.013$ & 11.77 & $34.2 \pm 1.9$ & $30.5 \pm 2.06$ \\
\hline
\end{tabular}

(The dates were done at the Quaternary U-series dating laboratory at Bergen University. The respective journal numbers are referred to in the first columns of tables II and III).

Table III . U-series Isochron data Svalbard G-27

\begin{tabular}{|c|c|c|c|c|c|c|c|c|c|c|c|}
\hline J.no & ${ }^{234} \mathrm{U} /{ }^{238} \mathrm{U}$ & \multicolumn{2}{|c|}{${ }^{230} \mathrm{Th} /{ }^{234} \mathrm{U}$} & \multicolumn{2}{|c|}{${ }^{230} \mathrm{Th} /{ }^{232} \mathrm{Th}$} & \multicolumn{3}{|c|}{${ }^{234} \mathrm{U} /{ }^{232} \mathrm{Th}$} & \multicolumn{3}{|c|}{${ }^{238} \mathrm{U} /{ }^{232} \mathrm{Th}$} \\
\hline 438 & $0.996 \pm 0.009$ & 0.470 & \pm 0.006 & 1.022 & \pm 0.006 & 2.173 & \pm & 0.007 & 2.182 & \pm & 0.020 \\
\hline 450 & $1.486 \pm 0.049$ & 0.299 & \pm 0.012 & 1.294 & \pm 0.011 & 4.334 & \pm & 0.016 & 2.917 & \pm & 0.215 \\
\hline 451 & $1.042 \pm 0.014$ & 0.262 & \pm 0.004 & 0.810 & \pm 0.004 & 3.094 & \pm & 0.004 & 2.970 & \pm & 0.042 \\
\hline 452 & $1.060 \pm 0.023$ & 1.272 & \pm 0.050 & 0.483 & \pm 0.050 & 0.380 & \pm & 0.069 & 0.358 & \pm & 0.073 \\
\hline 458 & $1.675 \pm 0.068$ & 0.694 & \pm 0.028 & 0.775 & \pm 0.028 & 1.117 & \pm & 0.029 & 0.667 & \pm & 0.090 \\
\hline 459 & $1.197 \pm 0.023$ & 0.542 & \pm 0.013 & 0.507 & \pm 0.013 & 0.935 & \pm & 0.010 & 0.781 & \pm & 0.025 \\
\hline 460 & $1.220 \pm 0.044$ & 0.784 & \pm 0.031 & 0.353 & \pm 0.031 & 0.450 & \pm & 0.026 & 0.369 & \pm & 0.038 \\
\hline
\end{tabular}

